\title{
Vaccine development against Leishmania donovani
}

\author{
Amrita Das and Nahid Ali * \\ Infectious Diseases and Immunology Division, Indian Institute of Chemical Biology, Kolkata, India
}

\section{Edited by:}

Swapan K. Ghosh, Indiana State

University, USA

\section{Reviewed by:}

Swapan K. Ghosh, Indiana State University, USA

Roy William Geib, Indiana University School of Medicine - Terre Haute,

USA

So-Yon Lim, Harvard Medical School, USA

Sampa Santra, Harvard Medical School, USA

*Correspondence:

Nahid Ali, Infectious Diseases and Immunology Division, Indian Institute of Chemical Biology, 4 Raja S.C. Mullick Road, Jadavpur, Kolkata 700032, India.

e-mail: nali@iicb.res.in
Visceral leishmaniasis (VL) caused by Leishmania donovani and Leishmania infantum/chagasi represents the second most challenging infectious disease worldwide, leading to nearly 500,000 new cases and 60,000 deaths annually. Zoonotic VL caused by L. infantum is a re-emergent canid zoonoses which represents a complex epidemiological cycle in the New world where domestic dogs serve as a reservoir host responsible for potentially fatal human infection and where dog culling is the only measure for reservoir control. Life-long immunity to VL has motivated development of prophylactic vaccines against the disease but very few have progressed beyond the experimental stage. No licensed vaccine is available till date against any form of leishmaniasis. High toxicity and increasing resistance to the current chemotherapeutic regimens have further complicated the situation in $V L$ endemic regions of the world. Advances in vaccinology, including recombinant proteins, novel antigen-delivery systems/adjuvants, heterologous prime-boost regimens and strategies for intracellular antigen presentation, have contributed to recent advances in vaccine development against VL. Attempts to develop an effective vaccine for use in domestic dogs in areas of canine $V L$ should be pursued for preventing human infection. Studies in animal models and human patients have revealed the pathogenic mechanisms of disease progression and features of protective immunity. This review will summarize the accumulated knowledge of pathogenesis, immune response, and prerequisites for protective immunity against human VL. Authors will discuss promising vaccine candidates, their developmental status and future prospects in a quest for rational vaccine development against the disease. In addition, several challenges such as safety issues, renewed and coordinated commitment to basic research, preclinical studies and trial design will be addressed to overcome the problems faced in developing prophylactic strategies for protection against this lethal infection.

Keywords: visceral leishmaniasis, vaccines, Leishmania donovani, immunoprophylaxis, kala-azar

\section{INTRODUCTION}

Leishmaniases are a wide spectrum of parasitic diseases caused by dimorphic protozoan flagellates of the genus Leishmania. These obligatory parasites of host macrophages are transmitted by $\sim 30$ different species of phlebotomine sandflies (Pearson and Sousa, 1996). Leishmaniasis accounts for global morbidity of 2.4 millions (946,000 for males and 1,410,000 for females) and a mortality rate of approximately 60,000 per year $^{1}$. Among the three clinical patterns of leishmaniasis (cutaneous, mucocutaneous, and visceral), visceral leishmaniasis (VL) is the most severe in terms of symptoms and clinical complications. Of the 500,000 new cases of VL every year, $90 \%$ occur in Bangladesh, Brazil, India, Ethiopia, Kenya and Sudan, countries that are strongly related to poverty (Hotez et al., 2004; Alvar et al., 2006). India alone accounts for more than half of the annual global VL infections, which is rapidly emerging as an important opportunistic HIV-coinfection.

Based on transmission characteristics, there are two types of VL: zoonotic VL caused by Leishmania infantum, and anthroponotic VL or kala-azar caused by Leishmania donovani. Kala-azar is

${ }^{1}$ http://www.who.int/tdr/disease/leish/direction.htm a systemic infection clinically characterized by prolonged fever, profound cachexia, hepatosplenomegaly, hypergammaglobulinemia, and pancytopenia, with an incubation period varying between 2 and 6 months (Bray, 1976; Chappuis et al., 2007). Almost all clinically symptomatic patients die within months if left untreated. Moreover, $5-10 \%$ of cured individuals from VL in India and 50\% in Sudan may also develop cutaneous manifestations in the form of macular, maculo-papular, and nodular skin lesions containing parasites, termed as post-kala-azar dermal leishmaniasis (PKDL). PKDL represents an important yet unclear issue of parasite persistence and the putative reservoir for kalaazar between epidemic cycles that need special attention for VL eradication (Addy and Nandy, 1992; Dereure et al., 2003).

In India the few therapeutic options registered for kala-azar include pentavalent antimonials (sodium stibogluconate), liposo$\mathrm{mal} /$ free amphotericin B, miltefosine, and paromomycin. However, all have one or more limitations or insufficiencies in the long run. Growing resistance to pentavalent antimonials, prohibitive cost of the available lipid formulations of amphotericin B, toxicity, need for hospitalization, HIV-coinfection, and increasing reports of relapse, have made the global demand for VL vaccine a major public health priority. Life-long immunity against 
reinfection indicates feasibility of successful vaccination against VL. However, no anti-leishmanial vaccine is still available for human use. Considerable inter-specific diversity of lipophosphoglycan (LPG) structure, extraordinary host evasive mechanism of the parasite and heterogeneity of human population (Beverley and Turco, 1998; Kaye and Scott, 2011) represent unprecedented challenges for VL vaccinology. Absence of an in vivo animal model accurately reflecting the clinical features of human VL adds to limitations of development of immunoprophylaxis against VL. However, current advances in genome sequencing and biotechnology have created a thrust for VL vaccinology an area which has been neglected for years. Development of a cross-protective anti-Leishmania vaccine is thus a desirable public health goal to combat this lethal infection.

Till date vaccine research against VL can be divided into three main groups: vaccination with live virulent or killed parasites (first generation vaccines), vaccination with whole-cell lysates/purified fractions, subunit vaccination with native/recombinant parasite proteins (second-generation vaccines), and plasmid DNA and viral vector based vaccines encoding parasite virulence factors (third generation vaccines). Recent concepts include use of genetically modified live-attenuated Leishmania parasites, and proteomics approach for the search of a cross-protective leishmanial vaccine that would ideally protect against both cutaneous and visceral forms of the disease.

\section{IMMUNOPATHOLOGY OF HUMAN VL: IMPLICATIONS FOR VACCINE DESIGN}

The clinical manifestations of leishmaniasis are determined not only by the parasite species but also by the general health and genetic constitution of the host (Bogdan et al., 1996; D'Oliveira Júnior et al., 1997). Understanding the immunological changes that are associated with resistance and susceptibility to the disease are fundamental to both designing as well as evaluating outcome of vaccines. Although mouse models have been used for study of both cutaneous and VL, very little is known about human VL.

Clinical studies reveal that human VL has a complex immunology characterized by mixed T-helper-1 (Th1)/T-helper-2 (Th2) cell milieu, where a suppressed Th1 response along with an elevated Th2 is the hallmark of the active disease. Conversely, protective immunity is achieved by upregulation of Th1 response after a successful chemotherapy (Hailu et al., 2001; Kubar and Fragaki, 2005). The crucial step in generating anti-leishmanial immunity is maintenance of the proportion of $\mathrm{CD}^{+}$and $\mathrm{CD} 8^{+}$ $\mathrm{T}$ cells that results in secretion of different cytokines required for immunomodulation in VL. Patients with kala-azar demonstrate negative delayed type hypersensitivity and non-proliferative response to parasite antigens (Sacks et al., 1987; Dominguez et al., 2002). Most of the $\mathrm{T}$ cell clones from the PBMCs of the active VL patients and asymptomatic subjects (seropositive and DTH positive) are $\mathrm{CD} 8^{+}$with negligible $\mathrm{CD} 4^{+}$, while the situation is reversed in the cured individuals with more numbers of $\mathrm{CD}^{+}$ than $\mathrm{CD}^{+}$cells (Saha et al., 2006). Probably, the CD4 ${ }^{+} \mathrm{T}$ cells are lost prior to $\mathrm{CD}^{+}$cells in $\mathrm{VL}$, thus a depressed $\mathrm{CD} 4: \mathrm{CD} 8$ ratio has been observed in patients compared with controls (Rohtagi et al., 1996; Clarêncio et al., 2009). Associated upregulation of immunosuppressive $\mathrm{CD} 4{ }^{+} \mathrm{CD} 25^{+}$regulatory $\mathrm{T}$ cells (Treg) in active VL patients probably leads to parasite persistence and chronic infection (Saha et al., 2007).

Cellular immunity is considered to be the key mediator of resistance by means of IFN- $\gamma$ that induces microbicidal activity against both the promastigotes and amastigote forms of $L$. donovani, in an $\mathrm{H}_{2} \mathrm{O}_{2}$-dependent (Murray and Cartelli, 1983; Murray et al., 1983) and NO-mediated pathway (Vouldoukis et al., 1997) for parasite clearance (Badaro et al., 1990; Badaro and Johnson, 1993; Harms et al., 1993; Squires et al., 1993; Sundar et al., 1994, 1995, 1997a,b; Sundar and Murray, 1995). Probably, impaired macrophage functions due to lack of detectable inducible NO synthase mRNA activity in liver and spleen fastens the disease progression in $L$. donovani infected hamsters, closely resembling the situation in human VL (Melby et al., 2001a). IL-12 is an immunoregulatory cytokine for initiation and maintenance of the Th1 response and plays an important role in the induction of IFN $-\gamma$ production by T and NK cells (Kobayashi et al., 1989; Stern et al., 1990; Scharton and Scott, 1993; Trinchieri, 1993). In VL patients, IL-12 enhances Th1 responses and restores lymphocyte proliferative responses, IFN $-\gamma$ production and cytotoxic responses (Ghalib et al., 1995; Bacellar et al., 1996). TNF- $\alpha$ is a proinflammatory chemokine associated with both protection and susceptibility to leishmaniasis. When produced at very high levels, TNF- $\alpha$ might have a diseaseenhancing effect (Karplus et al., 2002). IL-4, considered to be a marker of Th2 response, is present in the sera, PBMC supernatant (Zwingenberger et al., 1990; Sundar et al., 1997a) and as mRNA in active VL (Carvalho et al., 1994; Kenney et al., 1998). Although largely implicated in disease exacerbation (Zwingenberger et al., 1990), beneficial role of IL-4 in driving Th1 immunity for early protection against VL has also been suggested (Kamogawa et al., 1993; Alexander et al., 2000). IL-10 primarily down-modulates innate as well as acquired immune response. Moreover, IL-10 induction by host IgG-opsonized amastigotes leads to immune suppression of Th1 response with downregulation of IL-12 for disease progression (Caldas et al., 2005). Patients with VL have increased expression of mRNA for IL-10 in bone marrow and lymph nodes with enhanced levels of IL-10 in sera and leishmanial antigen-stimulated PBMC supernatants (Saha et al., 2007). Imbalanced IL-10 production may be associated with disease progression to PKDL (Ghalib et al., 1993; Saha et al., 2007). Transforming growth factor- $\beta$ (TGF- $\beta$ ) having immunosuppressive properties, is also documented in leishmaniasis disease progression (Nylén and Akuffo, 2009; Donaghy et al., 2010). A high level of total TGF- $\beta$ affects NO production by deactivating macrophages both in vitro and in vivo (Barral-Netto et al., 1992; Li et al., 1999). Recent studies have linked IL-13 (Babaloo et al., 2001), IL-15 (Carson et al., 1994, 1995; Armitage et al., 1995; Jullien et al., 1997; Milano et al., 2002), IL-17 and IL-22 (Pitta et al., 2009) with protection against $L$. donovani. IL-27, produced mainly by macrophages and DC, regulates Th17 cells thereby maintaining a balance between immunity and pathology in human VL (Anderson et al., 2009; Murugaiyan et al., 2009). Enhanced IL-27 in VL patients is shown to induce IL-21 which in turn promotes expansion of IL-10 secreting T cells, leading to parasite multiplication in spleen (Ansari et al., 2011).

Together with phagocytes, NK cells represent the first line of defense against pathogens by two principal mechanisms, cytolytic 
destruction of infected cells, and secretion of proinflammatory cytokines (e.g., IFN $\gamma$, TNF $\alpha$; Nylén et al., 2003). Activated NK cells promote DC maturation along with clearance of autologous immature DCs (Akuffo et al., 1993; Piccioli et al., 2002). Comparatively lower frequency of NK cells in active VL than controls further confirms their role in healing (Nylén et al., 2007). Conversely, DCs are pivotal in initiating and orchestrating the immune response by phagocytosis, antigen presentation, and cytokine production (Banchereau and Steinman, 1998; Mellman and Steinman, 2001). DCs essentially guide resistance or susceptibility to Leishmania by driving the differentiation and proliferation of $\mathrm{CD}^{+} \mathrm{T}$ cells toward one of the two polarized pathogen-specific Th1 or Th2 phenotype (Moser and Murphy, 2000). Differential roles of DCNK cell cross-talk at various stages of Leishmania infection present new insight on the interactions between innate immune components during infection with this parasite (Sanabria et al., 2008). Exploitation of DC biology may thus be a rationale of VL vaccine design for better antigen-delivery and presentation.

Although elevated levels of anti-leishmanial antibodies IgG, IgM, IgE, and IgG subclasses are well documented in active VL (Atta et al., 1998; Anam et al., 1999a,b; da Matta et al., 2000; Ryan et al., 2002; Ravindran et al., 2004), their precise role in protection against Leishmania is controversial and needs to be reappraised. IFN- $\gamma$ probably upregulates IgG1 and IgG3, while IL-4 and IL5 stimulate the production of high levels of $\operatorname{IgG}, \operatorname{IgM}$, IgE, and IgG subclasses like IgG4 in humans (Ozbilge et al., 2006). However, antibodies are not relevant for vaccine-induced protection in the absence of an appropriate cellular response. Overall, both $\mathrm{CD}^{+}{ }^{+}$and $\mathrm{CD} 8^{+} \mathrm{T}$ cells are required to mediate parasite control and successful vaccination requires IL- 12 driven IFN- $\gamma$-dependent Th1/Th2 mixed response against VL. However, high IL-4 and IL-10 production in immunized animals, despite very high IFN- $\gamma$, may lead to vaccine failure and disease exacerbation in VL (Bhowmick et al., unpublished data).

\section{COMPLEXITY OF HOST-PARASITE INTERACTION}

Leishmania spp. had been widely regarded as fastidious, obligate intracellular pathogens primarily inhabiting macrophages. But recent studies have confirmed their presence in hematopoietic cells having a common myeloid precursor (i.e., neutrophils, resident macrophages, dermal DCs, inflammatory monocyte-derived DCs) (Gueirard et al., 2008) and non-hematopoietic cells such as fibroblasts. Survival of Leishmania within the mammalian host depends on its ability to evade and manipulate the antileishmanial immune response to establish infection (Bogdan and Rollinghoff, 1998). Despite the presentation of leishmanial antigens and the initiation of inflammatory responses, Leishmania can reside within the host tissues for long periods of time by exploiting several evasive mechanisms (Zambrano-Villa et al., 2002). Opsonization of Leishmania promastigotes with parasitespecific IgG facilitates their uptake by macrophages and DCs which leads to establishment of infection (Prina et al., 2004). IL-12 produced by parasite-engulfed DCs, as a signature of anti-Leishmania protective response, is counteracted by immunosuppressive IL-10 produced by parasitized macrophages that activates host $\mathrm{T}_{\text {reg }}$ cells leading to disease progression (Woelbing et al., 2006). Notably LPG, the most abundant molecule constituting the glycocalyx of Leishmania promastigotes, plays an important role in the interactions between the parasite and the sandfly promoting the infectivity of the parasites. Considerable diversity in LPG structure among different Leishmania spp. explains their vector specificity (Sacks, 2001) and may also affect their immunological properties. Thus, LPG which is a virulence factor allowing safe passage and survival of metacyclic promastigotes in macrophages in L. major (Späth et al., 2000) and L. donovani (Desjardins and Descoteaux, 1997; Lodge et al., 2006; Vinet et al., 2009), has no such role in $L$. mexicana (Ilg, 2000). Profound differences in the virulence factors of L. major and L. donovani also affect their consequent pathologies as well as underlying immune evasive mechanisms, making development of a cross-protective vaccine difficult. Sandfly saliva itself can also act as a virulence factor by enhancing invasion of macrophages by promastigotes, even with low-dose inoculations (Gillespie et al., 2000). In fact, Leishmania has evolved numerous strategies to interfere with a broad range of macrophage signaling that includes protein kinase $\mathrm{C}$, the JAK2/STAT1 cascade, and the MAP kinase pathway that favor its survival and persistence in host cells (Shadab and Ali, 2011). Recruitment of inhibitory $\mathrm{CD}^{+}{ }^{+} \mathrm{CD} 25^{+} \mathrm{FoxP}^{+}{ }^{+}$regulatory $\mathrm{T}$ cells $\left(\mathrm{T}_{\text {reg }}\right)$ (Engwerda et al., 2004; Peters and Sacks, 2006; Nylén et al., 2007), inhibition of macrophage phagosomal maturation (interfering with fusion of phagosomes and lysosomes) (Olivier et al., 2005), and inhibition of DC maturation and chemotaxis (Brandonisio et al., 2004) are some of the strategies employed by Leishmania to evade effector mechanisms of the host immune system. Maturation of human monocyte-derived DCs is inhibited by both $L$. donovani and $L$. amazonensis (Favali et al., 2007; Tejle et al., 2008). Further, depletion of $\mathrm{CD}^{+}$T-cell following infection with $L$. donovani may contribute to chronic infection (Joshi et al., 2009). Thus, the main goal of Leishmania vaccinology is establishment of a Th1dominated cell-mediated response along with $\mathrm{CD}^{+} \mathrm{T}$ cells for sustained protective immunity (Scott, 2003).

Though it is often assumed that the type of disease depends solely on Leishmania species, susceptibility or resistance to leishmaniasis markedly varies within and between genetically diverse human populations (Walton and Valverde, 1979; Momeni and Aminjavaheri, 1994; Weigle and Saravia, 1996; Sharma et al., 2000; Bucheton et al., 2002). For example, PKDL is influenced by genetic polymorphism in IFN- $\gamma$ receptor (Mohamed et al., 2003), and susceptibility is linked to polymorphism in IL-4 gene in Sudanese patients (Blackwell et al., 2005). Natural resistanceassociated macrophage protein-1 (NRAMP1) has been shown to increase the risk of acquiring infection. In mice, Nramp1/Slc11a1 Lsh locus on chromosome 1 is responsible for acute susceptibility to L. donovani (Demant et al., 1996). However, its role in human is not clear. This difference is probably due to the fact that the Lsh/Nramp1/Slc11a1 allele in susceptible mice practically abolishes the gene function (equivalent to a traditional knockout), whereas polymorphisms in the promoter, exon 3 and the intron of human SLC11A1 are expected to have less influence on susceptibility to L. donovani (Bucheton et al., 2003; Mohamed et al., 2004). Polymorphisms in genes coding HLA class I and class II molecules have been related with susceptibility to L. guyanensis (Barbier et al., 1987) and L. braziliensis (Lara et al., 1991; Petzl-Erler et al., 1991) although impact of these polymorphisms on VL species 
seems ambiguous (Bucheton et al., 2003). Recent genome-wide linkage study from Sudan and Brazil has identified a putative susceptibility locus DLL1 (Delta-like 1 for Notch3) which is strongly implicated as the chromosome 6q27 VL susceptibility gene (Fakiola et al., 2011). In brief, further understanding of the complex yet unique species-specific virulence mechanisms, immunogenetics, and clinical correlates is needed for early diagnosis, customized chemotherapeutic strategies, and prophylaxis against VL.

\section{PROGRAMMING OF INNATE IMMUNITY}

The role of innate immune system comprising of macrophages, DCs, NK cells, and granulocytes forming the primary defense mechanism against pathogen, is gaining increasing attention in curing VL. Innate immune system is activated via pattern recognition receptors (PRRs) on host macrophages and DCs that recognize conserved pathogen-associated molecular patterns (PAMPs) of microbes. Activation of PRRs like Toll-like receptors (TLRs), nucleotide-binding domain (NOD)-like receptors and scavenger receptors by PAMPs leads to maturation and trafficking of the DCs to local lymph nodes for antigen presentation to naive T cells raising the adaptive immunity against the invading pathogen (Kaisho and Akira, 2000, 2001; Bocarsly et al., 2002). Again the pattern of TLR expression varies between the APC subsets and their anatomical locations (Banchereau and Steinman, 1998). Secretion of proinflammatory cytokines and chemokines following TLR activation contribute to Th1-independent immediate defense mechanisms (Hayashi et al., 2003). Bypassing these natural innate mechanisms by Leishmania promastigotes probably marks the beginning of successful parasitism. Leishmania adopts apparently quiescent mechanisms of macrophage entry with slow or negligible stimulation of NF- $\kappa \beta$ pathway which appears to be true for all Leishmania spp., thus delaying adaptive response. This has been experimentally evidenced in mice receiving low-dose parasite challenge in the ear (Belkaid et al., 2000). Plethora of evidence suggests a crucial role of TLR:PAMP interaction for bridging innate and adaptive immunity. Past experience with vaccine success of leishmanization (consisting of live virulent parasites) as against reduced protection by killed vaccines can possibly be assumed due to loss of parasite PAMPs during inactivation process which is required for establishing future adaptive immunity. To alleviate this problem, subunit or genetic vaccines are often adjuvanted with TLR-agonists for innate triggering of adaptive immunity to elicit robust cellular and humoral response. TLR ligands that mimic PAMPs to activate immune cells via Toll-like receptors (TLRs) are being developed for clinical use and immunotherapy against a variety of diseases. Adjuvant success of several TLR-agonists like CpGDNA (immunostimulatory oligodeoxynucleotides):TLR9 agonist, MPL (Monophosphoryl Lipid) A and GLA (Glucopyranosyl Lipid Adjuvant): TLR4 agonists, and imiquimod: TLR7 agonist, have been well documented against Leishmania (Buates and Matlashewski, 1999; Walker et al., 1999; Reed et al., 2003; Coler et al., 2007). Synthetic imidazoquinoline compounds (i.e., imiquimod and resiquimod) have been shown to activate human TLR7 and 8 (Gibson et al., 2002; Hemmi et al., 2002), and TLR7 in mice. TLR3 and TLR4 in synergy with TLR7, TLR8, and TLR9 in human and mouse DCs boost up Th1 response through increased production of IL-12 and IL-23. TLR synergy further establish DCs unidirectional intracellular cross-talk to acquire $\mathrm{T}$ cell response to a given vaccine in MyD88-dependent manner (Kang et al., 2002; Martinon and Tschopp, 2005; Napolitani et al., 2005; Zhu et al., 2008). Combinatorial synergy of MPL with CpG in L110f vaccine has shown to improve immunotherapy against murine CL probably resulting from chemokine RANTES (regulated upon activation normal $\mathrm{T}$ cell expressed and secreted) expression thereby recruiting activated $\mathrm{T}$ cells to the site of infection with enhanced IL-12 production (Raman et al., 2010). Future vaccination strategies using live non-virulent or genetically altered parasites with TLR 7/8 or TLR 4 agonists can be appropriate combination for priming innate immunity for durable, broad spectrum cross-protection against Leishmania. Designing of such novel multicomponent adjuvants combining TLRs and/or non-TLRs with vaccines for better amplification of T-cell and B-cell response merits further study.

\section{ANIMAL MODELS FOR VL}

Among several models tried for $L$. donovani, BALB/c mice and Syrian golden hamsters (Mesocricetus auratus) are the most extensively studied animal models for primary screening of vaccines and drugs. Absence of functional Sc11 1a1 locus in BALB/c and C57BL6 mice renders them susceptible to $L$. donovani infection compared to resistant CBA mice possessing functional Sc11 1algene that confers innate anti-leishmanial immunity (Bradley, 1974; Blackwell, 1996). Unlike L. major infection, Th1/Th2 dichotomy in cytokine milieu is not evident during murine VL caused by $L$. donovani/chagasi. The protective immunity in murine VL primarily depends on IL-12 driven Th1 response leading to increased IL-2 and IFN- $\gamma$ production for parasite killing. Substantial upregulation of inducible NO synthase (iNOS, NOS2) by IFN- $\gamma$ generates NO from splenic and liver macrophages thereby controlling parasite multiplication in these organs (Green et al., 1990; Blackwell, 1996). TGF- $\beta$, IL-10, and IL-13 are the major disease promoting cytokines leading to suppression of Th1 response (Wilson et al., 2005). Low levels of IL-4 usually enhance vaccine-induced protection by increasing IFN- $\gamma$ production from $\mathrm{CD}^{+}{ }^{+} \mathrm{T}$ cells (Stäger et al., 2003) and subsequently play no role in disease exacerbation in L. donovani infected mice. Despite the wide usage of the mouse model for vaccine studies in VL, this does not resemble the clinical outcomes seen in fatal human VL. Murine VL is largely subclinical and self-resolving disease compared to disseminated visceral infection which seems to be a major limitation in extrapolating the results to human VL. In mice, clearance of hepatic parasite burden occurs after 2 weeks post infection due to efficient granuloma formation resulting from interaction of Leishmania-specific $\mathrm{T}$ cells with parasitized dendritic cells and resident macrophages. Parasite killing in mature granulomas leads to resolution of hepatic infection in about 56 days in experimental VL. Hence, vaccine efficacy and disease progression in mice can be predicted from the degree of maturation of hepatic granulomas in challenged animals correlating with cell-mediated immunity (Murray et al., 1992; Carrión et al., 2006). In contrast to liver, spleen, and bone marrow act as the site of parasite persistence resulting in chronic infection in mice. The failure of parasitized marginal zone macrophages of spleen to produce IL-12, breakdown of splenic architecture and lack of granulomatous reaction leads to high parasite burden in spleen (Nieto 
et al., 2011). Infecting mice with large inoculums can thus be more suitable to resemble pathological changes similar to active human VL (Carrión et al., 2006). Interestingly, inoculating BALB/c mice with Indian L. donovani strains like AG83 leads to progressive VL with clinical manifestations of hepatosplenomegaly, at least up to 6 months post infection (Mazumder et al., 2004; Bhowmick et al., 2009). The disease progression in this model is associated with suppressed Th1 response due reduced IFN- $\gamma$ and IL-12 production from spleen cells along with enhanced IL-4 and IL-10, which get reversed with vaccine-induced protection. Further, infected mice also demonstrate high TGF- $\beta$ and low TNF- $\alpha 4$ months post infection resulting in impaired NO-mediated parasite clearance by macrophages (Bhowmick et al., 2009). However, precise correlates of pathology and protection are yet to be defined for this model for development of successful intervention against human VL.

Compared to mice, hamsters seem to a better model for progressive VL expressing clinical features like hepatosplenomegaly, immunosuppression, anemia, cachexia, and death, closely simulating human VL. Impaired macrophage activation in liver and spleen due to lack of NOS2 expression throughout disease progression seems to be the major cause of uncontrolled parasite multiplication and death in hamster (Melby et al., 2001a). High levels of TGF- $\beta$ have also been reported in tissues and cultured immune cells from mice and hamsters infected with $L$. donovani and $L$. chagasi, suggesting its definitive role in disease exacerbation (Müller et al., 1992; Gomes et al., 2000; Gantt et al., 2003). Increased secretion of TNF- $\alpha$ during later stage of disease probably results in profound weight loss in infected hamsters (Tracey et al., 1988). However, inadequacy of immunological reagents limits the use of hamster model for prophylactic and therapeutic analysis of VL. High innate susceptibility of hamsters to $L$. donovani makes them a more suitable model for studying immunopathology of VL than evaluation of protective immunity. Among several higher non-human primate models of VL, Indian langur monkey (Presbytis entellus) has shown consistent and progressive VL similar to active human disease. Immune protection achieved by autoclaved L. donovani (ALD) along with BCG in this model correlates with high IFN- $\gamma$, IL-2, and lymphoproliferation (Dube et al., 1998; Misra et al., 2001). Difficulties in laboratory handling, nonavailability and expense are some of the drawbacks of primate models that need to be solved for their routine use as VL models.

\section{VL VACCINE DEVELOPMENT: CONVENTIONAL APPROACHES FIRST GENERATION VACCINES}

"Leishmanization," the traditional practise of inoculating live, virulent Leishmania parasites from the exudates of a cutaneous lesion is the only successful intervention against leishmaniasis and has been practiced for centuries in Middle East and Russia with efficacy levels up to $100 \%$ (Nadim et al., 1983; Khamesipour et al., 2005). Based on persistence of parasites in the primary inoculated site for cellular response, leishmanization could confer virtually life-long and complete protection which is of utmost importance for developing anti-leishmanial vaccine. Unfortunately, features of adaptive immunity elicited for successful leishmanization have not been studied in human. It is known that previous exposure to L. major can confer protection against subsequent VL (Zijlstra et al., 1994). However, leishmanization trials have never been done either against New World tegumentary leishmaniasis or human VL. Although still practiced in Uzbekistan, severe side effects and complications have eventually replaced it by first generation killed Leishmania vaccines, with or without adjuvants. In order to improve safety of leishmanization, live L. major have been coinjected with CpG-DNA without compromising the vaccine potency in murine model (Mendez et al., 2003). Success of CpG adjuvanted live vaccine in murine CL apparently depended on CD4 Th17 cells and early recruitment of IFN- $\gamma$ secreting CD4 cells at inoculation site for long-term protection (Wu et al., 2010). This vaccine also resulted in activation of dermal DCs and NK cells for enhanced protection almost without any side effect unlike leishmanization. Although effective against VL in several experimental models, recent human clinical trials of killed vaccines have been found to be safe but not as effective as leishmanization, having low efficacies (54\%) when tested in humans (Sharifi et al., 1998; Momeni et al., 1999; Armijos et al., 2004; Vélez et al., 2005) and dogs (Genaro et al., 1996; Mohebali et al., 2004). The success of leishmanization over killed vaccines in CL can possibly be explained by an in vitro study evaluating human $\mathrm{T}$ cell function when simulated by live vs. killed parasites (Nateghi Rostami et al., 2010). In addition to increased IFN- $\gamma$ from $\mathrm{CD} 4^{+} \mathrm{T}$ cells, live parasites could also stimulate $\mathrm{CD}^{+} \mathrm{T}$ cells to secrete IFN- $\gamma$. Killed parasites, however, could stimulate $\mathrm{CD}^{+}{ }^{+} \mathrm{T}$ cells only. This probably accounts for better immunologic memory leading to sustained immunity after healing of live infections (Okwor and Uzonna, 2008; Nateghi Rostami et al., 2010). Promising enough, a very recent approach have generated a killed but metabolically active L. infantum chagasi promastigotes after treating them with amotosalen and low-dose UV radiation that resulted in replication-deficient parasites that could protect mice against experimental VL (Bruhn et al., 2012). These parasite could enter host macrophages for initial transformation for stimulating robust adaptive immunity for protection lasting up to 6 weeks post infection. However, most clinical trials have been conducted for CL with very few for VL (Khalil et al., 2000, 2006). The anticipated success with CL clinical trials may lead to a few human VL trials due to the highly conserved genomes of the Leishmania spp.

Ease of production, economy, and safety of first generation leishmanial vaccines have made them attractive for immunotherapeutic strategy against VL. Combination therapy comprising of alum-precipitated autoclaved L. major (ALM) with BCG has been found to be protective in PKDL patients significantly reducing cases of relapse (Musa et al., 2008). Killed Leishmania vaccines probably hold more prospects for immunotherapy combined with drugs than their single use against VL which needs further human trials.

\section{SECOND-GENERATION VACCINES}

\section{Vaccination with Leishmania fractions}

Partially or fully purified Leishmania subfractions have been widely used in experimental models (Gradoni, 2001; Handman, 2001) owing to their excellent immunoprotective properties. Previous studies showed that vaccination with fucose-mannose ligand (FML) protects against experimental VL in several animal models such as mice (Swiss Albino and BALB/c) and dog (Palatnik de 
Sousa et al., 1996; Santos et al., 1999, 2002; Parra et al., 2007). Additionally, membrane antigens of $L$. donovani promastigotes (LAg) entrapped in cationic liposomes could induce significant levels of protection in mice and hamsters (Afrin and Ali, 1997; Ali and Afrin, 1997; Afrin et al., 2000, 2002). Soluble leishmanial antigen (SLA) partially purified fraction from LAg, entrapped in cationic liposomes show both prophylactic and therapeutic efficacy against VL (Bhowmick et al., 2007). Moreover, immunostimulatory sequence bearing non-coding plasmid DNA co-entrapped in liposomal SLA showed Th1 biased immune protection in $\mathrm{BALB} / \mathrm{c}$ mice model of VL (Mazumder et al., 2007). Recently, fraction (F2) of $L$. donovani soluble promastigote antigen belonging to $97.4-68 \mathrm{kDa}$ has been identified for its ability to stimulate Th1-type cellular responses in cured VL patients and hamsters (Garg et al., 2006). Further fractionation of this F2-fraction revealed Th1-stimulatory polyproteins ranging from 89.9 to $97.1 \mathrm{kDa}$ that could offer longlasting protection against $L$. donovani in hamsters (Kumari et al., 2008a,b). However, difficulties in large-scale production, standardization of in vitro culture conditions and purification procedures are some of the issues raised regarding such vaccines to be considered for clinical trials against VL.

\section{Subunit protein vaccines}

Following hundreds of native and recombinant antigens tested inducing protection against $\mathrm{CL}$, several molecularly defined vaccine candidates have been evaluated against VL over the past two decades (Table 1). LPG was the first molecularly defined vaccine candidate against leishmaniasis that conferred protection against CL (Handman and Mitchell, 1985; McConville et al., 1987; Karanja et al., 2011). Concurrent studies with $L$. donovani-derived LPG suggested it as a promising candidate vaccine for transmission blocking (Tonui et al., 2001). The first recombinant antigen against leishmaniasis was gp63 or leishmanolysin, conserved in all Leishmania species. Although highly protective in its native form, both against CL (Kahl et al., 1990) and VL (Bhowmick et al., 2008), recombinant gp63 (rgp63) expressed in E. coli system failed to induce protection against CL (Handman et al., 1990). However, the reports remained controversial since BCG expressing gp63 showed protection in susceptible mice against $L$. major challenge (Abdelhak et al., 1995) which revealed that immunogenicity of processed peptides is not likely dependent upon its native structure. Additionally, recent reports of protection elicited by liposomal delivery of rgp63 via subcutaneous route, both against $L$. major (Jaafari et al., 2006, 2007) and L. donovani (Mazumder et al., 2011b) validate the use of liposomes as a critical parameter in these vaccination protocols. The high level of similarity in conserved residues of GP63 among different VL species: L. donovoni, L. chagasi, and $L$. infantum has recently been authenticated which suggests feasibility of a GP63-based vaccine success against VL (Sinha et al., 2011).

Nuclear histone protein $\mathrm{H} 2 \mathrm{~B}$ is another highly conserved antigen that is antigenic in several Leishmania species (Soto et al., 1999; Chenik et al., 2006). Analysis of the H2B showed sequence homology of carboxyl-terminal region among different Leishmania species, ensuring cross-specific protection. A recent study demonstrated that entire H2B protein is more efficient than its amino- or carboxyl-terminal in inducing a dominant Th1 profile that holds future against leishmaniasis (Meddeb-Garnaoui et al.,
2010). Considerable leishmanicidal properties (dose-dependent killing promastigotes of L. amazonensis, L. major, L. braziliensis, and L. mexicana) have also been demonstrated for histones $\mathrm{H} 2 \mathrm{~A}$ and $\mathrm{H} 2 \mathrm{~B}$ (but not histone $\mathrm{HI}^{0}$ ) (Wang et al., 2011) which show a new possibility of using these histone proteins for therapeutic vaccinations against leishmaniasis.

Open reading frame (ORFF), is a single copy gene, located on chromosome 35 as a part of the multigene LD1 locus, preferentially expressed in L. donovani amastigotes (Jain and Madhubala, 2008). Purified recombinant ORFF protein has been partially protective against $L$. donovani challenge in murine model (Tewary et al., 2004b). More recently, ORFF expressed as a chimeric ubiquitin conjugate was tested against antimony-sensitive and antimonyresistant strains of $L$. donovani as a vaccine candidate. This study demonstrated better protective efficacy of ubiquitin-conjugated ORFF than unconjugated one against experimental VL (Sharma and Madhubala, 2009). Several other subunit protein vaccines have been tested against different forms of leishmaniasis with varying success. These include dp72 (Jaffe et al., 1990; Aguilar-Be et al., 2005), ribosomal P0 protein (Iborra et al., 2005), Leishmania elongation factor 2 (LelF-2) (Kushawaha et al., 2011), amastigote cysteine proteases (Zadeh-Vakili et al., 2004), F14 (Bhardwaj et al., 2009), hydrophilic acylated surface protein B1 (HASPB1) (Stager et al., 2000), etc. The observation that some individuals exposed to uninfected sandfly mount a protective response to Leishmania (Davies and Mazloumi Gavgani, 1999) has lead to vaccine attempts designed against sandfly salivary proteins or insect gut antigens that can protect from infection (Morris et al., 2001). Recently, hamsters immunized with LMJ 19, a novel $11 \mathrm{kDa}$ protein from Lutzomya longipalpis saliva, were reported to be protected against VL (Gomes et al., 2008).

The use of synthetic peptide vaccines, particularly the T-cell epitopes also opened an interesting avenue in Leishmania vaccine since 1980s (Lamb et al., 1984; Jardim et al., 1990; Russo et al., 1993; Spitzer et al., 1999). However, this enthusiasm has waned in recent times due to inadequate memory response and inability of all individuals to respond to the peptide, which needs to be resolved.

Contrary to defined single antigen, multicomponent or polyprotein vaccines have been demonstrated to afford better protection against experimental VL. LEISH-F1 (formerly Leish111f), consisting of three recombinant antigens: Leishmania elongation initiation factor (LeIF), thiol-specific antioxidant (TSA), and $L$. major stress-inducible protein-1 (LmSTI1) is such a polyprotein vaccine that was able to confer protection against $L$. major (Skeiky et al., 2002) and L. infantum (Coler et al., 2007). A crucial component of LEISH-F1 vaccination is the selection of the adjuvant. The vaccine remained most efficacious when co-administered with IL-12, as well as detoxified derivative of lipid A from lipopolysaccharide (LPS) of Salmonella Minnesota, lipid A formulated with squalene in a stable emulsion (MPL-SE). LEISH-F1 + MPL-SE is the only second-generation vaccine that successfully cleared the clinical trial for safety and immunogenicity against VL (Vélez et al., 2009; Chakravarty et al., 2011).

Subunit vaccines based on recombinant proteins and synthetic peptides are safe. However, they are poor generators of cytotoxic T-cell (CTL) responses (Lima et al., 2004) and no single antigen could confer complete protection. To overcome this 
Table 1 | Second-generation vaccine candidates tested against $L$. donovani.

\begin{tabular}{|c|c|c|c|c|c|}
\hline Antigen & Vaccine form/adjuvant used & Animal model & Challenge infection & Result & Reference \\
\hline FML & Native antigen + Saponin & Hamster & L. donovani & Protection & $\begin{array}{l}\text { Palatnik de Sousa et al. } \\
\text { (1994a) }\end{array}$ \\
\hline FML & Native antigen + Saponin & Mouse & L. donovani & Protection & $\begin{array}{l}\text { Palatnik de Sousa et al. } \\
\text { (1994b) }\end{array}$ \\
\hline FML & $\begin{array}{l}\text { Native antigen + Saponin/Aluminum } \\
\text { hydroxide }\end{array}$ & Mouse & L. donovani & Protection & Santos et al. (1999) \\
\hline FML & Native antigen + IL-12/BCG/saponin & Mouse & L. donovani & Protection & Santos et al. (2002) \\
\hline $\mathrm{FML}$ & Native antigen + Quill A & Dog & L. donovani & Protection & Borja-Cabrera et al. (2002) \\
\hline $\mathrm{FML}$ & Native antigen + Saponin & Mouse & L. donovani & Protection & Santos et al. (2002) \\
\hline FML & Native antigen + Saponin & Mouse & L. donovani & Protection & $\begin{array}{l}\text { Palatnik de Sousa et al. } \\
\text { (2004) }\end{array}$ \\
\hline $\mathrm{LAg}$ & $\begin{array}{l}\text { Native antigen entrapped in cationic } \\
\text { liposome }\end{array}$ & Mouse/Hamster & L. donovani & Protection & $\begin{array}{l}\text { Afrin and Ali (1997), Ali and } \\
\text { Afrin (1997) }\end{array}$ \\
\hline $\mathrm{LAg}$ & $\begin{array}{l}\text { Native antigen entrapped in negatively } \\
\text { charged liposome }\end{array}$ & Mouse & L. donovani & Partial protection & Afrin et al. (2000) \\
\hline $\mathrm{LAg}$ & $\begin{array}{l}\text { Native antigen entrapped in cationic } \\
\text { liposome }\end{array}$ & Mouse & L. donovani & Protection & Mazumder et al. (2004) \\
\hline $\mathrm{LAg}$ & Native antigen entrapped in liposomes & Mouse & L. donovani & Protection & Bhowmick et al. (2010) \\
\hline $\mathrm{LAg}$ & $\begin{array}{l}\text { Native antigen + BCG/MPL/entrapped } \\
\text { in liposomes }\end{array}$ & Mouse & L. donovani & Protection & Ravindran et al. (2010) \\
\hline SLA & $\begin{array}{l}\text { Native antigen entrapped in cationic } \\
\text { liposome }\end{array}$ & Mouse & L. donovani & Protection & Bhowmick et al. (2007) \\
\hline SLA & $\begin{array}{l}\text { Native antigen + non-coding pDNA } \\
\text { co-entrapped in cationic liposome }\end{array}$ & Mouse & L. donovani & Protection & Mazumder et al. (2007) \\
\hline SLA & $\begin{array}{l}\text { Native antigen entrapped in cationic } \\
\text { liposome }+\mathrm{MPL}\end{array}$ & Mouse & L. donovani & Protection & Ravindran et al. (2012) \\
\hline gp36 & Native antigen + Saponin & Mouse & L. donovani & Protection & $\begin{array}{l}\text { Paraguai de Souza et al. } \\
\text { (2001) }\end{array}$ \\
\hline SA & Native antigen + CpG-ODN & Mouse & L. donovani & Protection & Tewary et al. (2004a) \\
\hline LD 31, 51, 72, 91 & $\begin{array}{l}\text { Native antigen entrapped in cationic } \\
\text { liposome }\end{array}$ & Mouse & L. donovani & Protection & Bhowmick and Ali (2009) \\
\hline gp70-2/dp72 & $\begin{array}{l}\text { Native antigen }+ \text { Corynebacterium } \\
\text { parvum }\end{array}$ & Mouse & L. donovani & Partial protection & Jaffe et al. (1990) \\
\hline Hsp70 + Hsp83 & Native antigen + MPL/ALD & Mouse & L. donovani & Protection & Kaur et al. (2011b) \\
\hline gp63 + Hsp70 & Native antigen & Mouse & L. donovani & Protection & Kaur et al. (2011a) \\
\hline LPG & Native antigen + BCG & Mouse/Hamster & L. donovani & No protection & Tonui et al. (2001) \\
\hline 78 kDa & Native antigen & Mouse & L. donovani & Protection & Mukherjee et al. (2002) \\
\hline $78 \mathrm{kDa}$ & $\begin{array}{l}\text { Native } \\
\text { antigen + MPL/ALD/liposome/FCA }\end{array}$ & Mouse & L. donovani & Protection & Nagill and Kaur (2010) \\
\hline $\mathrm{dp} 72$ & Native antigen & Mouse & L. donovani/L. major & Cross-protection & Rachamim and Jaffe (1993) \\
\hline gp63 & $\begin{array}{l}\text { Native antigen entrapped in cationic } \\
\text { liposome }\end{array}$ & Mouse & L. donovani & Protection & Bhowmick et al. (2008) \\
\hline $\mathrm{A} 2$ & $\begin{array}{l}\text { Recombinant } \\
\text { antigen + Propionibacterium acnes }\end{array}$ & Mouse & L. donovani & Protection & Ghosh et al. (2001b) \\
\hline HASPB1 & Recombinant antigen $+\mathrm{IL}-12$ & Mouse & L. donovani & Protection & Stager et al. (2000) \\
\hline gp63 & Recombinant antigen $+S$. typhimurium & Mouse & L. donovani/L. major & Cross- protection & McSorley et al. (1997) \\
\hline gp63 & $\begin{array}{l}\text { Recombinant antigen entrapped in } \\
\text { cationic liposome + MPL-TDM }\end{array}$ & Mouse & L. donovani & Protection & Mazumder et al. (2011a) \\
\hline F14 & Recombinant antigen + MPL & Hamster & L. donovani & Protection & Bhardwaj et al. (2009) \\
\hline Leishmune & Recombinant antigen & Dog & L. donovani & Protection & Nogueira et al. (2005) \\
\hline Leishmune & Recombinant antigen & Dog & L. donovani & Partial protection & Saraiva et al. (2006) \\
\hline
\end{tabular}




\section{Table 1 | Continued}

\begin{tabular}{|c|c|c|c|c|c|}
\hline Antigen & Vaccine form/adjuvant used & Animal model & Challenge infection & Result & Reference \\
\hline $\mathrm{ORFF}+\mathrm{BT} 1$ & Recombinant antigen & Mouse & L. donovani & Partial protection & Dole et al. (2000) \\
\hline ORFF & Recombinant antigen + CpG-ODN & Mouse & L. donovani & Partial protection & Tewary et al. (2004b) \\
\hline ORFF & Recombinant antigen & Mouse & L. donovani & Partial protection & Tewary et al. (2005) \\
\hline ORFF & Recombinant antigen + IL-12 DNA & Mouse & L. donovani & Protection & Tewary et al. (2005) \\
\hline $\mathrm{Ld} \gamma \mathrm{GCS}$ & Recombinant antigen entrapped in NIV & Mouse & L. donovani & Protection & Henriquez et al. (2010) \\
\hline LelF-2 & Recombinant antigen & Hamster & L. donovani & Protection & Kushawaha et al. (2011) \\
\hline
\end{tabular}

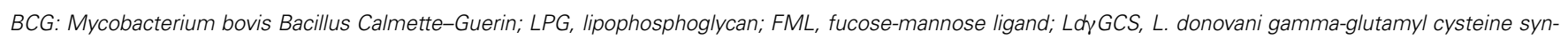

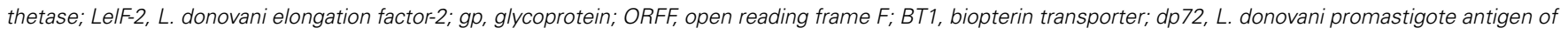
72 kDa; HASPB1, hydrophilic acylated surface protein B1; Hsp, heat-shock protein; LAg, leishmanial membrane antigen; NIV, non-ionic surfactant vesicle; CpG-ODN, CpG oligodeoxynucleotides; ALD, autoclaved L. donovani.

inherent problem of subunit vaccines, several studies are being carried out with promising adjuvants like Bacillus-CalmetteGuerin (BCG), alum, saponin, liposomes, MPLA, and other TLR ligands for vaccine success against VL (Bhowmick et al., 2008). Long-term immunity generated by subcutaneous immunization of liposomal soluble leishmanial antigen (SLA) with MPL-TDM (monophosphoryl lipid-trehalose dicorynomycolate) in BALB/c mice largely depends on high IFN $-\gamma$ and $\mathrm{CD} 8^{+} \mathrm{T}$ cells, along with downregulation of IL-4 (Ravindran et al., 2012). RAPSODI, a human-compatible second-generation vaccine is currently undergoing preclinical trial heading toward a pan-Leishmania vaccine (Rapsodi against leishmaniasis ${ }^{2}$; accessed 2 January 2012). Based on the most immunodominant antigen, promastigote surface antigen (PSA) expressed in L. tarentolae system (LEXSY, Jena Bioscience), RAPSODI holds a promising future for a cross-protective Leishmania vaccine.

\section{Dendritic cell (DC) - based vaccines}

DCs are a class of specialized APCs that orchestrate both innate and acquired immunity. TLR:PAMP interaction leads to maturation of DCs lying in the interface external environment and mucosal surface, inducing the expression of co-stimulatory molecules CD40, CD80, and CD86 required for T-cell activation. The secreted cytokines, namely IFNs and IL-12 drive the T-cell differentiation toward $\mathrm{CD} 4^{+}$Th1 or $\mathrm{CD}^{+}$CTL response. DC-based anti-leishmanial vaccines comprise a novel yet nascent strategy for long-lasting immunity (Moll and Berberich, 2001; Donaghy et al., 2010). Generation of parasite-specific Th1 biased long-term protection by plasmacytoid DC-based vaccination against $L$. major (Tsagozis et al., 2004; Remer et al., 2007) provided the thrust for targeting DC vaccines against VL. Adoptive transfer of DCs pulsed ex vivo with soluble L. donovani Ags (SLDA) to naive mice induced the Ag-specific production of IFN- $\gamma$. However, complete clearance of parasites from liver was attained only after IL-12-transduction of SLDA-pulsed DCs (Ahuja et al., 1999). This outlines the importance of paracrine delivery of IL-12 for DC-based vaccination. In a recent study, bone marrow-derived DCs (BM-DCs) pulsed ex vivo with the peptide 12-31aa portion of kinetoplastid membrane protein, KMP-11 (12-31aa) and CpG-ODN was protective

${ }^{2}$ http://www.fp7-rapsodi.eu/ in a murine model of VL (Agallou et al., 2011). In another study, combination therapy using SLDA-pulsed syngenic bone marrowderived DC and antimony-based chemotherapy could cure established murine VL via CD4 ${ }^{+}$T cell dependent Th1 response (Ghosh et al., 2003). Similar protective effects of microbial antigen-loaded DCs have also been reported for other pathogens (Bourguin et al., 1998; George-Chandy et al., 2001; McShane et al., 2002) and antitumour immunity (Kobukai et al., 2011). Another interesting approach has implemented hybrid cell vaccination therapy using L. donovani kinetoplastid membrane protein-11 (KMP11)-transfected bone marrow-derived macrophages from $B A L B / c$ mice with allogeneic bone marrow-derived DCs from C57BL/6 mice to resolve infection by establishing strong antigen-specific $\mathrm{CD}^{+}$CTL response (Basu et al., 2007). DCs have been proposed to play a critical role as immunomodulators in vaccination and therapy, and are therefore an important tool for prophylactic vaccination against serious infections. Integrating DC vaccinations with standard anti-leishmanial chemotherapy could thus be highly beneficial for therapeutic vaccination against VL. Nevertheless, this strategy has its limitations. Large-scale generation of leishmanial Ag-pulsed and/or cytokine-transduced autologous DC vaccine seems laborious and expensive, and could thus possibly limit its use in developing countries. Moreover, the choice of DC subtype, antigen-loading strategy, maturational status, route and frequency of immunization, and adjuvant cytokines all affect the performance of a DC vaccine.

\section{THIRD GENERATION VACCINES}

Genetic vaccination has been a better and flexible strategic alternative for inducing stronger Th1 biased immune response than their recombinant protein counterparts which often suffer from poor immunogenicity due to alerted pathoantigenic epitopes (Gurunathan et al., 1998; Rafati et al., 2006). An important feature of DNA vaccination is the induction of $\mathrm{CD}^{+}$cytotoxic $\mathrm{T}$ cells along with sufficient $\mathrm{CD} 4^{+} \mathrm{T}$ cell and humoral response. This contributes to cytolysis of parasite-infected cells by $\mathrm{CD}^{+} \mathrm{T}$ cells and increased IFN- $\gamma$ secretion for efficient leishmanicidal activity (Aguilar-Be et al., 2005; Carter et al., 2007). However, priming and expansion of $\mathrm{CD} 8^{+} \mathrm{T}$ cells solely depends upon $\mathrm{CD} 4^{+} \mathrm{T}$ cells which is vital for initiation and maintenance of immune memory (Bourgeois et al., 2002; Janssen et al., 2003). This concept of Th cell help for CTL response has led to further improvement 
of DNA vaccine constructs and adjuvant strategies over time. In addition to codon-optimized vectors, fusion of immune modulators (like CpG motifs, GM-CSF, Flt3 ligands, and cytokine genes) and novel delivery systems like electroporation, and the concept of heterologous prime-boosting have been employed successfully against Leishmania and several other pathogens. gp63, Leishmania analog of the receptor kinase C (LACK) and ORFF are the most extensively studied DNA vaccine candidates against VL till date (Table 2). Vaccination with a plasmid encoding LACK gene with or without co-administration of $1 \mathrm{~L}-12$ resulted in robust, longlasting protection in mice against L. major (Gurunathan et al., 1997, 1998; Stobie et al., 2000). Intranasal immunization with plasmid carrying LACK has also been protective against L. chagasi both in mice (Gomes et al., 2007) and hamster model (DE Oliveira Gomes et al., 2011) of VL. In contrast to LACK, which failed to protect against L. donovani (Melby et al., 2001b), priming with gp63 DNA with protein boost afforded robust, long-term protection in susceptible BALB/c mice (Mazumder et al., 2011b). Similarly, ORFF (Tewary et al., 2005), KMP-11 (Basu et al., 2005), and cysteine proteases (Rafati et al., 2006) have been protective as DNA vaccines against different Leishmania species. Protection was significantly improved when vaccines were composed of a cocktail of plasmids expressing immunodominant Leishmania genes. Accordingly, vaccination of mice with cocktail of plasmids harboring gp63 and Hsp70 genes elicited robust protection against $L$. donovani with enhanced IFN- $\gamma$ and IL-2 driving toward an excellent Th1 biased immune response (Kaur et al., 2011a). Further studies are required in higher animal models for such promising combination vaccines to ensure protection before they are finally evaluated in patients with VL. An interesting approach based on cDNA libraries has been adopted to identify protective L. donovani antigens through cDNA immunizations (Melby et al., 2000). Plasmid DNAs isolated from several cDNA sublibraries constructed from amastigote-derived RNA have been screened by immunization of BALB/c mice. Several groups of $\mathrm{CDNA}$ that conferred in vivo protection against subsequent $L$. donovani challenge have been identified by this technique.

Several lines of evidence suggest a central role of DCs in antigen presentation after DNA vaccination (Corr et al., 1996; Akbari et al., 1999) which explains the success of DCtargeted adjuvants like GM-CSF, TLRs, and Flt3 ligands when co-administered with plasmid DNA (Encke et al., 2006). LEISHDNAVAX, based on MIDGE vector, developed by Mologen AG (Berlin, Germany) is presently undergoing preclinical trials in Europe, against visceral and cutaneous forms of leishmaniasis, along with a double stem loop immunomodulator (DSLIM)

Table 2 |Third generation vaccine candidates for $L$. donovani.

\begin{tabular}{|c|c|c|c|c|c|}
\hline Antigen & Vaccine form/adjuvant used & Animal model & Challenge infection & Result & Reference \\
\hline \multicolumn{6}{|c|}{ L. DONOVANI-DERIVED ANTIGENS TESTED AGAINST L. DONOVANI } \\
\hline p36 LACK & DNA vaccine $+\mathrm{IL}-12$ & Mouse & L. donovani & No protection & Melby et al. (2001b) \\
\hline A2 & DNA vaccine & Mouse & L. donovani & Protection & Ghosh et al. (2001a) \\
\hline A2 & $\begin{array}{l}\text { Expressed in Lactococcus } \\
\text { lactis }\end{array}$ & Mouse & L. donovani & Protection & Yam et al. (2011) \\
\hline ORFF & DNA vaccine & Mouse & L. donovani & Partial protection & Sukumaran et al. (2003) \\
\hline ORFF-HPB & $\begin{array}{l}\text { DNA vaccine + recombinant } \\
\text { protein }\end{array}$ & Mouse & L. donovani & Protection & Tewary et al. (2005) \\
\hline ORFF & $\begin{array}{l}\text { Ubiquitin conjugated DNA } \\
\text { vaccine }\end{array}$ & Mouse & L. donovani & Protection & $\begin{array}{l}\text { Sharma and Madhubala } \\
\text { (2009) }\end{array}$ \\
\hline KMP-11 & DNA vaccine & Hamster & L. donovani & Protection & Basu et al. (2005) \\
\hline KMP-11 & DNA vaccine + IL-12 & Mouse & L. donovani, L. major & Cross-protection & Bhaumik et al. (2009) \\
\hline$\gamma \mathrm{GCS}$ & DNA vaccine & Mouse & L. donovani & Protection & Carter et al. (2007) \\
\hline $\mathrm{H} 2 \mathrm{~A}, \mathrm{H} 2 \mathrm{~B}, \mathrm{H} 3, \mathrm{H} 4, \mathrm{LACK}$ & Multiantigen DNA vaccine & Dog & L. donovani & Partial protection & Saldarriaga et al. (2006) \\
\hline PPG-N-terminal domain & DNA vaccine & Hamster & L. donovani & Protection & Samant et al. (2009) \\
\hline gp63/polytope & $\begin{array}{l}\text { DNA vaccine/polytope/polytope } \\
\text { fused with hsp70 }\end{array}$ & Mouse & L. donovani & Protection & Sachdeva et al. (2009) \\
\hline P1-HPB & $\begin{array}{l}\text { DNA vaccine + recombinant } \\
\text { protein }\end{array}$ & Hamster & L. donovani & Protection & Masih et al. (2011) \\
\hline gp63-HPB & $\begin{array}{l}\text { DNA vaccine + recombinant } \\
\text { protein + CpG-ODN }\end{array}$ & Mouse & L. donovani, L. major & Cross-protection & Mazumder et al. (2011b) \\
\hline \multicolumn{6}{|c|}{ L. DONOVANI-DERIVED ANTIGENS TESTED AGAINST OTHER LEISHMANIA SPECIES } \\
\hline $\mathrm{NH} 36$ & DNA vaccine & Mouse & L. chagasi, L. mexicana & Cross-protection & Aguilar-Be et al. (2005) \\
\hline $\mathrm{NH} 36$ & DNA vaccine & Mouse & L. chagasi & Protection & Gamboa-León et al. (2006) \\
\hline A2 & Expressed in adenovirus & Mouse & L. chagasi & Protection & Resende et al. (2008) \\
\hline A2 & Expressed in L. tarentolae & Mouse & L. infantum & Protection & Mizbani et al. (2009) \\
\hline
\end{tabular}

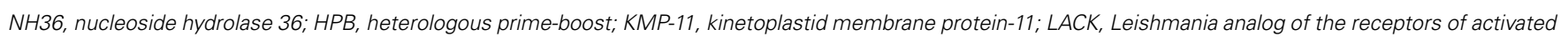
C kinase; $P P G$, proteophosphoglycan. 
adjuvant [Development of a DNA vaccine for VL: LEISHDNAVAX. European Commission Research-Health; ${ }^{3}$ (accessed 2 January 2012)]. This multicomponent vaccine with three to four known immunodominant leishmanial antigens holds a great therapeutic and prophylactic potential against VL. Finally, safety issues must be ensured during these early steps of DNA vaccine development for human acceptance.

\section{VL VACCINE DEVELOPMENT: NEW STRATEGIES GENETICALLY ALTERED LIVE-ATTENUATED VACCINE}

Vaccination with genetically modified Leishmania parasite is based on decoupling virulence for induction of protective immunity. This generally involves targeted disruption of virulence or essential leishmanial genes resulting in mutated parasites lacking virulence. These mutants closely mimic the natural course of infection through PAMPs required for adequate stimulation of innate immunity for long-term immune memory. Such live-attenuated vaccines have been successfully used against several viral and bacterial pathogens (Nakhasi et al., 1989; Larsen et al., 2009). Despite several attempts, very limited numbers of genetically modified live-attenuated forms of $L$. donovani exist as vaccine candidates. Recently, L. donovani centrin null mutants ( $\mathrm{Ld} \mathrm{Cen}^{-} /^{-}$) have been reported to protect BALB/c mice and Syrian hamsters against homologous as well as heterologous infectious challenge (Selvapandiyan et al., 2009). Immune protection upon 10 week post-virulent challenge correlated with Th1 biased response with significant increase in IFN- $\gamma$, IL-12, and TNF producing T cells that significantly lowered the parasite burden in spleen along with complete clearance of parasites in liver. Similar Th1 biased protection has been shown in mice immunized with L. donovani biopterin transporter null mutant $\left(\mathrm{BT}^{-/-}\right.$) (Papadopoulou et al., 2002) and silent information regulatory 2 single-knock out mutants (Li SIR2 ${ }^{ \pm}$) of L. infantum against virulent challenge (Silvestre et al., 2007). Similarly, cytochrome C oxidase component p27 null mutants ( $\mathrm{Ld} \mathrm{p} 27^{-/-}$) of $L$. donovani showed less virulence both in human macrophages and in $\mathrm{BALB} / \mathrm{c}$ mice (Dey et al., 2010) which may be explored further. More recently, a preliminary evaluation using $L$. infantum heat-shock protein (HSP70-II) null mutant seems promising in inducing protection in L. major-BALB/c infection model (Carrión et al., 2011).

An interestingly different approach using non-pathogenic species like $L$. tarentolae as live vaccine showed enhanced antigen presentation and potent Th1 response against $L$. donovani challenge in BALB/c mice (Breton et al., 2005). Further refinement of this approach using recombinant $L$. tarentolae expressing $L$. donovani A2 antigen was cross-protective against both $L$. infantum (Mizbani et al., 2009, 2011) and L. donovani (Yam et al., 2011). Overall, the use of live, non-pathogenic/genetically engineered Leishmania seems to be the most promising strategic alternative against VL. However, the underlying risk of reversion to virulence chiefly in immunocompromised individuals is an important limitation for their large-scale use. Additionally, presence of antibiotic resistant genes in attenuated parasite strains hinders their use in clinical studies. Moreover, safety blocking of vaccine strain

${ }^{3} \mathrm{http}: / /$ cc.europa.eu/research/health/infectious-diseases/neglected-diseases/ projects/006 en.html transmissibility by sandfly vector is another important issue that needs clarification.

\section{PROTEOMIC APPROACHES}

Proteomics, being widely applied in studying Leishmania spp., is a powerful tool for elucidating both molecular pathology and mechanistic searching of novel vaccine targets often missed following conventional techniques. Current immunoproteomics using twodimensional gel electrophoresis (2-DE) and matrix-assisted laser desorption/ionization mass spectrometry (MALDI-MS) approach focuses on identification and evaluation of responses to parasite T-cell epitopes as putative vaccine targets. Recent proteomeserological methodology using 2-D Western blot analyses from clinical isolates and sera of Indian VL patients have led to detection of 330 different immunogenic antigens (Forgber et al., 2006). Another systematic study detected a total of 33 T-cell stimulating antigens from soluble proteins of $L$. donovani clinical isolate, M.W. ranging from 68 to $97.4 \mathrm{kDa}$ (Gupta et al., 2007) that showed significant prophylactic potential against $L$. donovani challenge in hamster model of VL (Garg et al., 2006). Availability of annotated $32.8-\mathrm{Mb}$ sequenced genome with 8272 protein coding genes ${ }^{4}$ of $L$. major permits identification of all potential protein products precisely outlining heterogeneity of complex host responses to leishmanial antigenic variation, and will be useful in rational designing of vaccine. Additional proteomic approaches analyzing sandfly salivary components have identified a large prospective candidate repertoire for vaccine development against leishmaniasis (Titus and Ribeiro, 1988; Gillespie et al., 2000; Valenzuela et al., 2004).

However, the field of proteomics in Leishmania mostly limits itself to cytosolic proteins thereby excluding many pathogenic extracellular membrane proteins due to difficulties in solubilizing their hydrophobic transmembrane domains. Also, the approach remains insufficient for identification of protein subsets actually being expressed in parasites. Combining biological functions of identified proteins via activity-based techniques would accelerate this process of post-genomic vaccine research in future.

\section{SUBTRACTIVE GENOMICS}

A very recently adopted methodology is based on subtraction of sequence between host and parasite proteome. Availability of whole genome sequence for human and pathogenic microbes has been utilized to find non-human homologous vaccine and therapeutic targets against Helicobacter pylori (Huynen et al., 1998; Dutta et al., 2006), Pseudomonas aeruginosa (Sakharkar et al., 2004; Perumal et al., 2007), Mycobacterium pneumonia (Gupta et al., 2010), Borrelia burgdorferi (Madagi et al., 2011), Chlamydia trachomatis (Praveena et al., 2011) as well as L. donovani (Mandage and Wadnerkar, 2010) that are currently facing the problems of drug resistance or absence of vaccines. Thus sorted key pathogenic proteins essential for parasite survival but nonhomologous to human host, are subsequently checked for their cellular localization within the pathogen, exo-membrane topology and role in metabolic pathways to be used for drug or

\footnotetext{
${ }^{4}$ http//www. genedb.org/leish/index.jsp
} 
prophylactic targets. Usually, conserved secreted and membrane proteins from pathogens are selected to design novel vaccines (Dutta et al., 2006; Barh et al., 2010). A preliminary work based on computational subtractive genomics has identified protein kinase, adenylate kinase and MAP kinase homolog of L. donovani for regulating normal cell cycle and differentiation of the parasite (Mandage and Wadnerkar, 2010). The experimental evaluation of such vaccine targets is required to validate their prophylactic potential. Further prediction of functional sites and exploration of Leishmania proteome are required to get the full benefit of this approach for a cross-protective VL vaccine. Moreover, it is advisable to consider all the pathogenic strains undertaking in silico mutagenesis approach and pangenomics data base, for further improvement of this basic strategy.

\section{CHALLENGES AND FUTURE PROSPECT}

A major challenge in vaccination against Leishmania and several other intracellular pathogens is the requirement of strong cellmediated immune response in mediating protection. Most of the licensed prophylactic vaccines for human use rely completely on humoral response which have limited efficacy against Leishmania. Although adjuvants like alum, AS04 (composed of MPLA adsorbed to alum), MF59 and AS03 (oil-in-water emulsion) are approved for human use, inability to trigger robust T-cell response remains a potential short-coming of killed/subunit vaccines. None of the Leishmania vaccines reaching clinical trials could show adequate efficacy due to poor $\mathrm{CD}^{+}{ }^{-} \mathrm{T}$-cell responses arising from inefficient cross-presentation. Live-attenuated vaccines are advantageous in generating durable cellular (both $\mathrm{CD}^{+}$and $\mathrm{CD}^{+}$) response mostly due to temporary parasite persistence and proper antigen presentation. However, they are largely precluded due to safety reasons. Although, in the current scenario, a plasmid DNA vaccine following heterologous prime-boost strategy seems to be a promising prophylactic choice for generating robust cellular and humoral response, they are largely tempered by chances of chronic inflammation, autoantibody generation and systemic lupus erythematosus (SLE), or integration into host genome that may either activate oncogenes or deactivate tumor suppressor genes. Further, optimization in terms of magnitude of T-cell response and safety is warranted for genetic vaccinations before human administration. Additionally, most of the commonly used immunological

\section{REFERENCES}

Abdelhak, S., Louzir, H., Timm, J., Blel, L., Benlasfar, Z., Lagranderie, M., Gheorghiu, M., Dellagi, K., and Gicquel, B. (1995). Recombinant BCG expressing the leishmania surface antigen Gp63 induces protective immunity against Leishmania major infection in BALB/c mice. Microbiology 141, 1585-1592.

Addy, M., and Nandy, A. (1992). Ten years of kala-azar in west Bengal, Part I. Did post-kala-azar dermal leishmaniasis initiate the outbreak in 24-Parganas? Bull. World Health Organ. 70, 341-346.

Afrin, F., and Ali, N. (1997). Adjuvanticity and protective immunity

assays for evaluating adaptive immunity in vaccinated animals are often insufficient and need to be revitalized. Adoption of newer sophisticated technologies like multiparametric flow cytometry for evaluating magnitude and quality of multifunctional $\mathrm{T}$ cells simultaneously producing IFN- $\gamma$, IL-2, IL-10, and TNF- $\alpha$ can be acquired for better correlation with diverse immunopathogenesis and protection (Selvapandiyan et al., 2009; Macedo et al., 2012). Similarly, parasite quantification in challenged animals by real-time PCR can help quantify as little as 0.1 parasites thereby improving the accuracy of detection compared to conventional microscopic counting of organ smear impressions and limiting dilution assay (Nicolas et al., 2002).

Today's Leishmania vaccine research is focused upon bridging the common cellular and molecular components of different but interdependent systems of innate and adaptive immunity by certain immunomodulators to raise highly integrated defense against the parasites. Although all new vaccine approaches may not succeed in inducing sustained life-long immunity against VL, a shortterm Th1 biased response may also be appreciated for its therapeutic prospects. Interestingly, cationic liposomes alone can stimulate DCs with upregulation of CD80 and CD86 co-stimulatory molecules to generate humoral as well as $\mathrm{CD}^{+}$and $\mathrm{CD}^{+}{ }^{+} \mathrm{T}$-cell response resulting in activation of MHC-II and MHC-I pathways for antigen presentation. Formulating these cationic vesicles with lipid -based TLR ligands like MPL, imiquimods, etc. can be safe, immensely potent adjuvants against VL, for stronger combined CTL and antibody response. Moreover, the immunological paradigm governing natural resistance to $L$. donovani in certain individuals from Indian endemic pockets of VL remains unexplored, which can be immensely informative for vaccine design. In conclusion, correct orientations of innate biology and adjuvant research fine tuned with emerging fields of immunoproteomics, Leishmania genome mining and system biology can lead to absolute prophylactic anti-leishmanial vaccine in the near future.

\section{ACKNOWLEDGMENTS}

This work was supported by grants from the Council of Scientific and Industrial Research and the Department of Science and Technology, Government of India. We thank Sarfaraz Ahmad Ejazi for his assistance during preparation of the manuscript.

Agallou, M., Margaroni, M., and Karagouni, E. (2011). Cellular vaccination with bone marrow-derived dendritic cells pulsed with a peptide of Leishmania infantum KMP-11 and $\mathrm{CpG}$ oligonucleotides induces protection in a murine model of visceral leishmaniasis. Vaccine 29, 5053-5064.

Aguilar-Be, I., da Silva Zardo, R., Paraguai de Souza, E., BorjaCabrera, G. P., Rosado-Vallado, M., Mut-Martin, M., García-Miss Mdel, R., Palatnik de Sousa, C. B., and Dumonteil, E. (2005). Cross-protective efficacy of a prophylactic Leishmania donovani DNA vaccine against visceral and cutaneous murine leishmaniasis. Infect. Immun.73, 812-819.

Ahuja, S. S., Reddick, R. L., Sato, N., Montalbo, E., Kostecki, V., Zhao, W., Dolan, M. J., Melby, P. C., and Ahuja, S. K. (1999). Dendritic cell (DC)-based anti-infective strategies: DCs engineered to secrete IL-12 are a potent vaccine in a murine model of an intracellular infection. J. Immunol. 163, 3890-3897.

Akbari, O., Panjwani, N., Garcia, S., Tascon, R., Lowrie, D., and Stockinger, B. (1999). DNA vaccination: transfection and activation of dendritic cells as key events for immunity. $J$. Exp. Med. 189, 169-178. 
Akuffo, H., Maasho, K., and Howe, R. (1993). Natural and acquired resistance to Leishmania: cellular activation by Leishmania aethiopica of mononuclear cells from unexposed individuals is through the stimulation of natural killer (NK) cells. Clin. Exp. Immunol. 94, 516-521.

Alexander, J., Carter, K. C., Al-Fasi, N., Satoskar, A., and Brombacher, F. (2000). Endogenous IL-4 is necessary for effective drug therapy against visceral leishmaniasis. Eur. J. Immunol. 30, 2935-2943.

Ali, N., and Afrin, F. (1997). Protection of mice against visceral leishmaniasis by immunization with promastigote antigen incorporated in liposomes. J. Parasitol. 83, 70-75.

Alvar, J., Yactayo, S., and Bern, C. (2006). Leishmaniasis and poverty. Trends Parasitol. 22, 552-557.

Anam, K., Afrin, F., Banerjee, D., Pramanik, N., Guha, S. K., Goswami, R. P., Gupta, P. N., Saha, S. K., and Ali, N. (1999a). Immunoglobulin subclass distribution and diagnostic value of Leishmania donovani antigen-specific immunoglobulin G3 in Indian kala-azar patients. Clin. Diagn. Lab. Immunol. 6, 231-235.

Anam, K., Afrin, F., Banerjee, D., Pramanik, N., Guha, S. K., Goswami, R. P., Saha, S. K., and Ali, N. (1999b). Differential decline in Leishmania membrane antigenspecific immunoglobulin $\mathrm{G}(\mathrm{IgG})$, IgM, IgE, and IgG subclass antibodies in Indian kala-azar patients after chemotherapy. Infect. Immun. 67, 6663-6669.

Anderson, C. F., Stumhofer, J. S., Hunter, C. A., and Sacks, D. (2009). IL27 regulates IL-10 and IL-17 from CD4+ cells in nonhealing Leishmania major infection. J. Immunol. 183, 4619-4627.

Ansari, N. A., Kumar, R., Gautam, S., Nylén, S., Singh, O. P., Sundar, S., and Sacks, D. (2011). IL27 and IL-21 are associated with T cell IL-10 responses in human visceral leishmaniasis. J. Immunol. 186, 3977-3985.

Armijos, R. X., Weigel, M. M., Hidalgo, A., Cevallos, W., and Correa, J. (2004). Safety, immunogenicity, and efficacy of an autoclaved Leishmania amazonensis vaccine plus BCG adjuvant against New World cutaneous leishmaniasis. Vaccine 22, 1320-1326.

Armitage, R. J., MacDuff, B. M., Eisenman, J., Paxton, R., and Grabstein, K. H. (1995). IL-15 has stimulatory activity for the induction of $\mathrm{B}$ cell proliferation and differentiation. $J$. Immunol. 154, 483-490.
Atta, A. M., D'Oliveira, C. J., Atta, M. L., Almeida, R. P., and Carvalho, E. M. (1998). Anti-leishmanial IgE antibodies: a marker of active disease in visceral leishmaniasis. Am. J. Trop. Med. Hyg. 59, 426-430.

Babaloo, Z., Kaye, P. M., and Eslami, M. B. (2001). Interleukin-13 in Iranian patients with visceral leishmaniasis: relationship to other Th2 and Th1 cytokines. Trans. R. Soc. Trop. Med. Hyg. 95, 85-88.

Bacellar, O., Brodskyn, C., Guerreiro, J., Barral-Netto, M., Costa, C. H., Coffman, R. L., Johnson, W. D., and Carvalho, E. M. (1996). Interleukin-12 restores interferon-gamma production and cytotoxic responses in visceral leishmaniasis. J. Infect. Dis. 173, 1515-1518.

Badaro, R., Falcoff, E., Badaro, F. S., Carvalho, E. M., Pedral-Sampaio, D., Barral, A., Carvalho, J. S., BarralNetto, M., Brandely, M., Silva, L., Bina, J. C., Teixeira, R., Falcoff, R., Rocha, H., Ho, J. L., and Johnson, W. D. Jr. (1990). Treatment of visceral leishmaniasis with pentavalent antimony and interferon gamma. $N$. Engl. J. Med. 322, 16-21.

Badaro, R., and Johnson, W. D. Jr. (1993). The role of interferongamma in the treatment of visceral and diffuse cutaneous leishmaniasis. J. Infect. Dis. 167, 13-17.

Banchereau, J., and Steinman, R. M. (1998). Dendritic cells and the control of immunity. Nature 392, 245-252.

Barbier, D., Demenais, F., Lefait, J. F., David, B., Blanc, M., Hors, J., and Feingold, N. (1987). Susceptibility to human cutaneous leishmaniasis and HLA, Gm, Km markers. Tissue Antigens 30, 63-67.

Barh, D., Misra, A. N., and Kumar, A. (2010). In silico identification of dual ability of $\mathrm{N}$. gonorrhoeae ddl for developing drug and vaccine against pathogenic Neisseria and other human pathogens. J. Proteomics Bioinform. 3, 082-090.

Barral-Netto, M., Barral, A., Brownell, C. E., Skeiky, Y. A., Ellingsworth, L. R., Twardzik, D. R., and Reed, S. G. (1992). Transforming growth factorbeta in leishmanial infection: a parasite escape mechanism. Science 257, 545-548.

Basu, R., Bhaumik, S., Basu, J. M., Naskar, K., De, T., and Roy, S. (2005). Kinetoplastid membrane protein-11 DNA vaccination induces complete protection against both pentavalent antimonial-sensitive and resistant strains of Leishmania donovani that correlates with inducible nitric oxide synthase activity and
IL-4 generation: evidence for mixed Th1- and Th2-like responses in visceral leishmaniasis. J. Immunol. 174 7160-7171.

Basu, R., Bhaumik, S., Haldar, A. K., Naskar, K., De, T., Dana, S. K., Walden, P., and Roy, S. (2007). Hybrid cell vaccination resolves Leishmania donovani infection by eliciting a strong CD8+ cytotoxic Tlymphocyte response with concomitant suppression of interleukin-10 (IL-10) but not IL-4 or IL-13. Infect. Immun. 75, 5956-5966.

Belkaid, Y., Mendez, S., Lira, R., Kadambi, N., Milon, G., and Sacks, D. (2000). A natural model of Leishmania major infection reveals a prolonged "silent" phase of parasite amplification in the skin before the onset of lesion formation and immunity. J. Immunol. 165 , 969-977.

Beverley, S. M., and Turco, S. J. (1998), Lipophosphoglycan (LPG) and the identification of virulence genes in the protozoan parasite Leishmania. Trends Microbiol. 6, 35-40.

Bhardwaj, S., Vasishta, R. K., and Arora, S. K. (2009). Vaccination with a novel recombinant Leishmania antigen plus MPL provides partial protection against $L$. donovani challenge in experimental model of visceral leishmaniasis. Exp. Parasitol. 121, 29-37.

Bhaumik, S., Basu, R., Sen, S., Naskar K., and Roy, S. (2009). KMP-11DNA immunization significantly protects against $L$. donovani infection but requires exogenous IL-12 as an adjuvant for comparable protection against L. major. Vaccine 27 1306-1316.

Bhowmick, S., and Ali, N. (2009). Identification of novel Leishmania donovani antigens that help define correlates of vaccine-mediated protection in visceral leishmaniasis. PLoS ONE 4, e5820. doi:10.1371/journal.pone. 0005820

Bhowmick, S., Mazumdar, T., and Ali, N. (2009). Vaccination route that induces transforming growth factor beta production fails to elicit protective immunity against Leishmania donovani infection. Infect. Immun. 77, 1514-1523.

Bhowmick, S., Mazumdar, T., Sinha, R., and Ali, N. (2010). Comparison of liposome based antigen delivery systems for protection against Leishmania donovani. J. Control Release 141 199-207.

Bhowmick, S., Ravindran, R., and Ali, N (2007). Leishmanial antigens in liposomes promote protective immunity and provide immunotherapy against visceral leishmaniasis via polarized Th1 response. Vaccine 25 , 6544-6556.

Bhowmick, S., Ravindran, R., and Ali, N. (2008). gp63 in Stable cationic liposomes confers sustained vaccine immunity to susceptible BALB/C mice infected with Leishmania donovani. Infect. Immun. 76, 1003-1015.

Blackwell, J. M. (1996). Genetic susceptibility to leishmanial infections: studies in mice and man. Parasitology 112 (Suppl.), S67-S74.

Blackwell, J. M., Mohamed, H. S., and Ibrahim, M. E. (2005). Genetics and visceral leishmaniasis in the Sudan: seeking a link. Trends Parasitol. 20 268-274.

Bocarsly, P., Tomai, M. A., and Vasilakos, J. P. (2002). Plasmacytoid dendritic cells produce cytokines and mature in response to the TLR7 agonists, imiquimod and resiquimod. Cell. Immunol. 218, 74-86.

Bogdan, C., Gessner, A., Solbach, W., and Röllinghoff, M. (1996). Invasion, control and persistence of Leishmania parasites. Curr. Opin. Immunol. 84, 517-525.

Bogdan, C., and Rollinghoff, M. (1998). The immune response to Leishmania: mechanisms of parasite control and evasion. Int. J. Parasitol. 28 , 121-134.

Borja-Cabrera, G. P., Correia Pontes, N. N., da Silva, V. O., Paraguai de Souza, E., Santos, W. R., Gomes, E. M., Luz, K. G., Palatnik, M., and Palatnik de Sousa, C. B. (2002). Long lasting protection against canine kala-azar using the FML-QuilA saponin vaccine in an endemic area of Brazil (São Gonçalo do Amarante, RN). Vaccine 20, 3277-3284.

Bourgeois, C., Veiga-Fernandes, H., Joret, A. M., Rocha, B., and Tanchot, C. (2002). CD8 lethargy in the absence of CD4 help. Eur. J. Immunol. 32, 2199-2207.

Bourguin, I., Moser, M., Buzoni-Gatel, D., Tielemans, F., Bout, D., Urbain, J., and Leo, O. (1998). Murine dendritic cells pulsed in vitro with Toxoplasma gondii antigens induce protective immunity in vivo. Infect. Immun. 66, 4867.

Bradley, D. J. (1974). Letter: genetic control of natural resistance to Leishmania donovani. Nature 250, 353-354.

Brandonisio, O., Spinelli, R., and Pepe, M. (2004). Dendritic cells in Leishmania infection. Microbes Infect. 6 , 1402-1409.

Bray, R. S. (1976). "Immunodiagnosis of leishmaniasis," in Immunology of Parasite Infection, eds $\mathrm{S}$. Cohen and E. H. Sadun (Oxford: 
Blackwell Scientific Publications), 65-66.

Breton, M., Tremblay, M. J., Ouellette, M., and Papadopoulou, B. (2005). Live nonpathogenic parasitic vector as a candidate vaccine against visceral leishmaniasis. Infect. Immun. 73, 6372-6782.

Bruhn, K. W., Birnbaum, R., Haskell, J., Vanchinathan, V., Greger, S., Narayan, R., Chang, P. L., Tran, T. A., Hickerson, S. M., Beverley, S. M., Wilson, M. E., and Craft, N. (2012). Killed but metabolically active Leishmania infantum as a novel wholecell vaccine for visceral leishmaniasis. Clin. Vaccine Immunol. 19, 490-498.

Buates, S., and Matlashewski, G. (1999). Treatment of experimental leishmaniasis with the immunomodulators imiquimod and S-28463: efficacy and mode of action. J. Infect. Dis. 179, 1485-1494.

Bucheton, B., Abel, L., Kheir, M. M., Mirgani, A., El-Safi, S. H., Chevillard, C., and Dessein, A. (2003). Genetic control of visceral leishmaniasis in a Sudanese population: candidate gene testing indicates a linkage to the NRAMP1 region. Genes Immun. 4, 104-109.

Bucheton, B., Kheir, M. M., El-Safi, S. H., Hammad, A., Mergani, A., Mary, C., Abel, L., and Dessein, A. (2002). The interplay between environmental and host factors during an outbreak of visceral leishmaniasis in eastern Sudan. Microbes Infect. 14, 1449-1457.

Caldas, A., Favali, C., Aquino, D., Vinhas, V., van Weyenbergh, J., Brodskyn, C., Costa, J., Barral-Netto, M., and Barral, A. (2005). Balance of IL-10 and interferon-gamma plasma levels in human visceral leishmaniasis: implications in the pathogenesis. BMC Infect. Dis. 5, 113. doi:10.1186/1471-2334-5-113

Carrión, J., Folgueira, C., Soto, M., Fresno, M., and Requena, J. M. (2011). Leishmania infantum HSP70-II null mutant as candidate vaccine against leishmaniasis: a preliminary evaluation. Parasit. Vectors 4, 150.

Carrión, J., Nieto, A., Iborra, S., Iniesta, V., Soto, M., Folgueira, C., Abanades, D. R., Requena, J. M., and Alonso, C. (2006). Immunohistological features of visceral leishmaniasis in $\mathrm{BALB} / \mathrm{c}$ mice. Parasite Immunol. 28 , 173-183.

Carson, W. E., Giri, J. G., Lindermann, M. J., Linett, M. L., Ahdieh, M., Paxton, R., Anderson, D., Eisenmann, J., Grabstein, K., and Caligiuri, M. A. (1994). Interleukin-(IL)-15 is a novel cytokine that activates human natural killer cells via components of the IL-2 receptor. J. Exp. Med. 180, 1395-1403.

Carson, W. E., Ross, M. E., Baiocchi, R. A., Marien, M. J., Boiani, N., Grabstein, K., and Caligiuri, M. A. (1995). Endogenous production of interleukin-15 by activated human monocytes is critical for optimal production of interferon-gamma by natural killer cells in vitro. J. Clin. Invest. 96, 2578-2582.

Carter, K. C., Henriquez, F. L., Campbell, S. A., Roberts, C. W., Nok, A., Mullen, A. B., and McFarlane, E. (2007). DNA vaccination against the parasite enzyme gamma glutamylcysteinesynthetase confers protection against Leishmania donovani infection. Vaccine 25, 4502-4509.

Carvalho, E. M., Bacellar, O., Brownell, C., Regis, T., Coffman, R. L., and Reed, S. G. (1994). Restoration of IFN-gamma production and lymphocyte proliferation in visceral leishmaniasis. J. Immunol. 152, 5949-5956.

Chakravarty, J., Kumar, S., Trivedi, S., Rai, V. K., Singh, A., Ashman, J. A., Laughlin, E. M., Coler, R. N., Kahn, S. J., Beckmann, A. M., Cowgill, K. D., Reed, S. G., Sundar, S., and Piazza, F. M. (2011). A clinical trial to evaluate the safety and immunogenicity of the LEISH-F1+MPL-SE vaccine for use in the prevention of visceral leishmaniasis. Vaccine 29, 3531-3537.

Chappuis, F., Sundar, S., Hailu, A., Ghalib, H., Rijal, S., Peeling, R. W., Alvar, J., and Boelaert, M. (2007). Visceral leishmaniasis: what are the needs for diagnosis, treatment and control? Nat. Rev. Microbiol. 5, 873-882.

Chenik, M., Louzir, H., Ksontini, H., Dilou, A., Abdmouleh, I., and Dellagi, K. (2006). Vaccination with the divergent portion of the protein histone $\mathrm{H} 2 \mathrm{~B}$ of Leishmania protects susceptible $\mathrm{BALB} / \mathrm{c}$ mice against a virulent challenge with Leishmania major. Vaccine 24, 2521-2529.

Clarêncio, J., de Oliveira, C. I., Favali, C., Medina, O., Caldas, A., Costa, C. H., Costa, D. L., Brodskyn, C., Barral, A., and Barral-Netto, M. (2009). Could the lower frequency of CD8+CD18+CD45RO+ lymphocytes be biomarkers of human VL? Int. Immunol. 212, 137-144.

Coler, R. N., Yasuyuki, G., Bogatzki, L., Raman, V., and Reed, S. G. (2007). Leish-111f, a recombinant polyprotein vaccine that protects against visceral leishmaniasis by elicitation of CD4 T cells. Infect. Immun. 75, 4648-4654.

Corr, M., Lee, D. J., Carson, D. A., and Tighe, H. (1996). Gene vaccination with naked plasmid DNA: mechanism of CTL priming. J. Exp. Med. 184, 1555-1560.

da Matta, V. L., Hoshino-Shimizu, S., Dietze, R., and Corbett, C. E (2000). Detection of specific antibody isotypes and subtypes before and after treatment of American visceral leishmaniasis. J. Clin. Lab. Anal. 14, 5-12.

Davies, C. R., and Mazloumi Gavgani, A. S. (1999). Age, acquired immunity and the risk of visceral leishmaniasis: a prospective study in Iran. Parasitology 119, 247-257.

DE Oliveira Gomes, D. C., DA Silva Costa Souza, B. L., DE Matos Guedes, H. L., Lopes, U. G. and Rossi-Bergmann, B. (2011). Intranasal immunization with LACK-DNA promotes protective immunity in hamsters challenged with Leishmania chagasi. Parasitology 138, 1892-1897.

Demant, P., Lipoldova, M., and Svobodova, M. (1996). Resistance to Leishmania major in mice. Science 274, 1392-1393.

Dereure, J., El-Safi, S. H., Bucheton, B, Boni, M., Kheir, M. M., Davoust, B., Pratlong, F., Feugier, E., Lambert, M., Dessein, A., and Dedet, J. P. (2003). Visceral leishmaniasis in eastern Sudan: parasite identification in humans and dogs; host-parasite relationships. Microbes Infect. 5, 1103-1108.

Desjardins, M., and Descoteaux, A. (1997). Inhibition of phagolysosomal biogenesis by the Leishmania lipophosphoglycan. J. Exp. Med. 185, 2061-2068.

Dey, R., Meneses, C., Salotra, P., Kamhawi, S., Nakhasi, H. L., and Duncan, R. (2010). Characterization of a Leishmania stagespecific mitochondrial membrane protein that enhances the activity of cytochrome $c$ oxidase and its role in virulence. Mol. Microbiol. 77, 399-414.

Dole, V. S., Raj, V. S., Ghosh, A., Madhubala, R., Myler, P. J., and Stuart, K. D. (2000). Immunization with recombinant LD1 antigens protects against experimental leishmaniasis. Vaccine 19, 423-430.

D’Oliveira Júnior, A., Costa, S. R., Barbosa, A. B., Orge M de la, G., and Carvalho, E. M. (1997). Asymptomatic Leishmania chagasi infection in relatives and neighbors of patients with visceral leishmaniasis.
Mem. Inst. Oswaldo Cruz 92, 15-20.

Dominguez, M., Moreno, I., LopezTrascasa, M., and Torano, A. (2002). Complement interaction with trypanosomatid promastigotes in normal human serum. J. Exp. Med. 195, 451-459.

Donaghy, L., Cabillic, F., Corlu, A., Rostan, O., Toutirais, O., GuguenGuillouzo, C., Guiguen, C., and Gangneux, J. P. (2010). Immunostimulatory properties of dendritic cells after Leishmania donovani infection using an in vitro model of liver microenvironment. PLoS Negl. Trop. Dis. 4, e703. doi:10.1371/journal.pntd.0000703

Dube, A., Sharma, P., Srivastava, J. K., Misra, A., Naik, S., and Katiyar, J. C. (1998). Vaccination of langur monkeys (Presbytis entellus) against Leishmania donovani with autoclaved $L$. major plus BCG. Parasitology 116(Pt 3), 219-221.

Dutta, A., Singh, S. K., Ghosh, P., Mukherjee, R., Mitter, S., and Bandyopadhyay, D. (2006). In silico identification of potential therapeutic targets in the human pathogen Helicobacter pylori. In silico Biol. (Gedrukt) 6, 43-47.

Encke, J., Bernardin, J., Geib, J., Barbakadze, G., Bujdoso, R., and Stremmel, W. (2006). Genetic vaccination with Flt3-L and GM-CSF as adjuvants: enhancement of cellular and humoral immune responses that results in protective immunity in a murine model of hepatitis $c$ virus infection. World J. Gastroenterol. 12, 7118-7125.

Engwerda, C. R., Ato, M., and Kaye, P. M. (2004). Macrophages, pathology and parasite persistence in experimental visceral leishmaniasis. Trends Parasitol. 20, 524-530.

Fakiola, M., Miller, E. N., Fadl, M. Mohamed, H. S., Jamieson, S. E., Francis, R. W., Cordell, H. J., Peacock, C. S., Raju, M., Khalil, E. A., Elhassan, A., Musa, A. M., Silveira, F., Shaw, J. J., Sundar, S., Jeronimo, S. M., Ibrahim, M. E., and Blackwell, J. M. (2011). Genetic and functional evidence implicating DLL1 as the gene that influences susceptibility to visceral leishmaniasis at chromosome 6q27. J. Infect. Dis. 204, $467-477$.

Favali, C., Tavares, N., Clarêncio, J., Barral, A., Barral-Netto, M., and Brodskyn, C. (2007). Leishmania amazonensis infection impairs differentiation and function of human dendritic cells. J. Leukoc. Biol. 82, 1401-1406. 
Forgber, M., Basu, R., Roychoudhury, K., Theinert, S., Roy, S., Sundar, S., and Walden, P. (2006). Mapping the antigenicity of the parasites in Leishmania donovani infection by proteome serology. PLoS ONE 1, e40. doi:10.1371/journal.pone.0000040

Gamboa-León, R., Paraguai de Souza, E., Borja-Cabrera, G. P., Santos, F. N., Myashiro, L. M., Pinheiro, R. O., Dumonteil, E., and Palatnik-deSousa, C. B. (2006). Immunotherapy against visceral leishmaniasis with the nucleoside hydrolase-DNA vaccine of Leishmania donovani. Vaccine 24, 4863-4873.

Gantt, K. R., Schultz-Cherry, S., Rodriguez, N., Jeronimo, S. M., Nascimento, E. T., Goldman, T. L., Recker, T. J., Miller, M. A., and Wilson, M. E. (2003). Activation of TGF beta by Leishmania chagasi: importance for parasite survival in macrophages. J. Immunol. 170, 2613-2620.

Garg, R., Gupta, S. K., Tripathi, P., Hajela, K., Sundar, S., Naik, S., and Dube, A. (2006). Leishmania donovani: identification of stimulatory soluble antigenic proteins using cured human, and hamster lymphocytes for their prophylactic potential against visceral leishmaniasis. Vaccine 24, 2900-2909.

Genaro, O., de Toledo, V. P., da Costa, C. A., Hermeto, M. V., Afonso, L. C., and Mayrink, W. (1996). Vaccine for prophylaxis and immunotherapy, Brazil. Clin. Dermatol. 14, 503-512.

George-Chandy, A., Mielcarek, N., Nordström, I., Holmgren, J., and Eriksson, K. (2001). Vaccination with Bordetella pertussis-pulsed autologous or heterologous dendritic cells induces a mucosal antibody response in vivo and protects against infection. Infect. Immun. 69, 4120-4124.

Ghalib, H. W., Piuvezam, M. R., Skeiky, Y. A., Siddig, M., Hashim, F. A., elHassan, A. M., Russo, D. M., and Reed, S. G. (1993). Interleukin 10 production correlates with pathology in human Leishmania donovani infections. J. Clin. Invest. 92, 324-329.

Ghalib, H. W., Whittle, J. A., Kubin, M., Hashim, F. A., el-Hassan, A. M., Grabstein, K. H., Trinchieri, G., and Reed, S. G. (1995). IL12 enhances Thl-type responses in human Leishmania donovani infections. J. Immunol. 154, 4623-4629.

Ghosh, A., Labrecque, S., and Matlashewski, G. (2001a). Protection against Leishmania donovani infection by DNA vaccination: increased DNA vaccination efficiency through inhibiting the cellular p53 response. Vaccine 19, 3169-3178.

Ghosh, A., Zhang, W. W., and Matlashewski, G. (2001b). Immunization with $\mathrm{A} 2$ protein results in a mixed Th1/Th2 and a humoral response which protects mice against Leishmania donovani infections. Vaccine 20, 59-66.

Ghosh, M., Pal, C., Ray, M., Maitra, S., Mandal, L., and Bandyopadhyay, S. (2003). Dendritic cellbased immunotherapy combined with antimony-based chemotherapy cures established murine visceral leishmaniasis. J. Immunol. 170, 5625-5629.

Gibson, S. J., Lindh, J. M., Riter, T. R., Gleason, R. M., Rogers, L. M., Fuller, A. E., Oesterich, J. L., Gorden, K. B., Qiu, X., McKane, S. W., Noelle, R. J., Miller, R. L., Kedl, R. M., FitzgeraldBocarsly, P., Tomai, M. A., and Vasilakos, J. P. (2002). Plasmacytoid dendritic cells produce cytokines and mature in response to the TLR7 agonists, imiquimod and resiquimod. Cell. Immunol. 218, 74-86.

Gillespie, R. D., Mbow, M. L., and Titus, R. G. (2000). The immunomodulatory factors of blood feeding arthropod saliva. Parasite Immunol. 22, 319-331.

Gomes, N. A., Gattass, C. R., BarretoDe-Souza, V., Wilson, M. E., and DosReis, G. A. (2000). TGF-beta mediates CTLA-4 suppression of cellular immunity in murine kalaazar. J. Immunol. 164, 2001-2008.

Gomes, D. C., Pinto, E. F., de Melo, L. D., Lima, W. P., Larraga, V., Lopes, U. G., and Rossi-Bergmann, B. (2007). Intranasal delivery of naked DNA encoding the LACK antigen leads to protective immunity against visceral leishmaniasis in mice. Vaccine 25, 2168-2172.

Gomes, R., Teixeira, C., Teixeira, M. J., Oliveira, F., Menezes, M. J., Silva, C., de Oliveira, C. I., Miranda, J. C., Elnaiem, D. E., Kamhawi, S., Valenzuela, J. G., and Brodskyn, C. I. (2008). Immunity to a salivary protein of a sand fly vector protects against the fatal outcome of visceral leishmaniasis in a hamster model. Proc. Natl. Acad. Sci. U.S.A. 105, 7845-7850.

Gradoni, L. (2001). An update on antileishmanial vaccine candidates and prospects for a canine Leishmania vaccine. Vet. Parasitol. 100, 87-103.

Green, S. J., Meltzer, M. S., Hibbs, J. B. Jr., and Nacy, C. A. (1990). Activated macrophages destroy intracellular Leishmania major amastigotes by an
L-arginine-dependent killing mechanism. J. Immunol. 144, 278-283.

Gueirard, P., Laplante, A., Rondeau, C., Milon, G., and Desjardins, M. (2008). Trafficking of Leishmania donovani promastigotes in nonlytic compartments in neutrophils enables the subsequent transfer of parasites to macrophages. Cell. Microbiol. 10, 100-111.

Gupta, S. K., Singh, S., Gupta, M. K., Pant, K. K., and Seth, P. K. (2010). Identification of potential targets in Mycoplasma pneumonia through subtractive genome analysis. J. Antivir. Antiretrovir. 2, 038-041.

Gupta, S. K., Sisodia, B. S., Sinha, S., Hajela, K., Naik, S., Shasany, A. K., and Dube, A. (2007). Proteomic approach for identification and characterization of novel immunostimulatory proteins from soluble antigens of Leishmania donovani promastigotes. Proteomics 7 , 816-823.

Gurunathan, S., Prussin, C., Sacks, D. L., and Seder, R. A. (1998). Vaccine requirements for sustained cellular immunity to an intracellular parasitic infection. Nat. Med. 4, 1409-1415.

Gurunathan, S., Sacks, D. L., Brown, D. R., Reiner, S. L., Charest, H., Glaichenhaus, N., and Seder, R. A.(1997). Vaccination with DNA encoding the immunodominant LACK parasite antigen confers protective immunity to mice infected with Leishmania major. J. Exp. Med. 186, 1137-1147.

Hailu, A., Menon, J. N., Berhe, N., Gedamu, L., Hassard, T. H., Kager, P. A., Olobo, J., and Bretscher, P. A. (2001). Distinct immunity in patients with visceral leishmaniasis from that in subclinically infected and drug-cured people: implications for the mechanism underlying drug cure. J. Infect. Dis. 184, 112-115.

Handman, E. (2001). Leishmaniasis: current status of vaccine development. Clin. Microbiol. Rev. 14, 229-243.

Handman, E., Button, L. L., and McMaster, R. W. (1990). Leishmania major: production of recombinant gp63, its antigenicity and immunogenicity in mice. Exp. Parasitol. 70, 427-435.

Handman, E. and Mitchell G. F. (1985). Immunization with Leishmania receptor for macrophages protects mice against cutaneous leishmaniasis. Proc. Natl. Acad. Sci. U.S.A. 82, 5910-5914.

Harms, G., Zwingenberger, K., Sandkamp, B., Omena, S., Pedrosa, C.,
Richter, J., Rosenkaimer, F., Feldmeier, H., and Bienzle, U. (1993). Immunochemotherapy of visceral leishmaniasis: a pilot trial of sequential treatment with recombinant interferon-gamma and pentavalent antimony. J. Interferon Res. 13, 39-41.

Hayashi, F., Means, T. K., and Luster, A. D. (2003). Toll-like receptors stimulate human neutrophil function. Blood 10, 2660-2669.

Hemmi, H., Kaisho, T., Takeuchi, O., Sato, S., Sanjo, H., Hoshino, K., Horiuchi, T., Tomizawa, H., Takeda, K., and Akira, S. (2002). Small anti-viral compounds activate immune cells via the TLR7 MyD88-dependent signaling pathway. Nat. Immunol. 3, 196-200.

Henriquez, F. L., Campbell, S. A., Roberts, C. W., Mullen, A. B., Burchmore, R., and Carter, K. C. (2010). Vaccination with recombinant Leishmania donovani gammaglutamylcysteine synthetase fusion protein protects against $L$. donovani infection. J. Parasitol. 96, 929-936.

Hotez, P. J., Remme, H. F., Buss, P., George, G., Morel, C., and Breman, J. G. (2004). Combating tropical infectious diseases: report of the disease control priorities in developing countries project. Clin. Infect. Dis. 38, 871-878.

Huynen, M., Dandekar, T., and Bork, P. (1998). Differential genome analysis applied to the species-specific features of Helicobacter pylori. FEBS Lett. 426, 1-5.

Iborra, S., Carrión, J., Anderson, C., Alonso, C., Sacks, D., and Soto, M. (2005). Vaccination with the Leishmania infantum acidic ribosomal P0 protein plus CpG oligodeoxynucleotides induces protection against cutaneous leishmaniasis in C57BL/6 mice but does not prevent progressive disease in $\mathrm{BALB} / \mathrm{c}$ mice. Infect. Immun. 73, 5842-5852.

Ilg, T. (2000). Lipophosphoglycan is not required for infection of macrophages or mice by Leishmania mexicana. EMBO J. 19, 1953-1962.

Jaafari, M. R., Badiee, A., Khamesipour, A., Samiei, A., Soroush, D., Kheiri, M. T., Barkhordari, F., McMaster, W. R., and Mahboudi, F. (2007) The role of $\mathrm{CpG}$ ODN in enhancement of immune response and protection in $\mathrm{BALB} / \mathrm{c}$ mice immunized with recombinant major surface glycoprotein of Leishmania (rgp63) encapsulated in cationic liposome. Vaccine 25, 6107-6117.

Jaafari, M. R., Ghafarian, A., FarrokhGisour, A., Samiei, A., Kheiri, M. T., Mahboudi, F., Barkhordari, F., 
Khamesipour, A., and McMaster, W. R. (2006). Immune response and protection assay of recombinant major surface glycoprotein of Leishmania (rgp63) reconstituted with liposomes in $\mathrm{BALB} / \mathrm{c}$ mice. Vaccine $24,5708-5717$

Jaffe, C. L., Rachamim, N., and Sarfstein, R. (1990). Characterization of two proteins from Leishmania donovani and their use for vaccination against visceral leishmaniasis. J. Immunol. 144, 699-706.

Jain, M., and Madhubala, R. (2008). Characterization and localization of ORFF gene from the LD1 locus of Leishmania donovani. Gene 416, $1-10$.

Janssen, E. M., Lemmens, E. E., Wolfe, T., Christen, U., von Herrath, M. G., and Schoenberger, S. P. (2003). $\mathrm{CD} 4+\mathrm{T}$ cells are required for secondary expansion and memory in CD8+ T lymphocytes. Nature 421, 852-856.

Jardim, A., Alexander, J., Teh, H. S., Ou, D. W., and Olafson, R. W. (1990). Immunoprotective Leishmania major synthetic T cell epitopes. J. Exp. Med. 172, 645-648.

Joshi, T., Rodriguez, S., Perovic, V., Cockburn, I. A., and Stager, S. (2009). B7-H1 blockade increases survival of dysfunctional CD8+ $\mathrm{T}$ cells and confers protection against Leishmania donovani infections. PLoS Pathog. 5, e1000431. doi:10.1371/journal.ppat.1000431

Jullien, D., Sieling, P. A., Uyemura, K., Mar, N. D., Rea, T. H., and Modlin, R. L. (1997). IL-15, an immunomodulator of $\mathrm{T}$ cell responses in intracellular infection. J. Immunol. 158, 800-806.

Kahl, L. P., Lelchuk, R., Scott, C. A., and Beesley, J. (1990). Characterization of Leishmania major antigenliposomes that protect $\mathrm{BALB} / \mathrm{c}$ mice against cutaneous leishmaniasis. Infect. Immun. 58, 3233-3241.

Kaisho, T., and Akira, S. (2000). Critical roles of Toll-like receptors in host defense. Crit. Rev. Immunol. 20, 393-405.

Kaisho, T., and Akira, S. (2001). Toll-like receptors and their signaling mechanism in innate immunity. Acta Odontol. Scand. 59, 124-130.

Kamogawa, Y., Minasi, L. A., Carding, S. R., Bottomly, K., and Flavell, R. A. (1993). The relationship of IL-4and IFN gamma-producing $\mathrm{T}$ cells studied by lineage ablation of IL-4producing cells. Cell 75, 985-995.

Kang, D. C., Gopalkrishnan, R. V., Wu, Q., Jankowsky, E., Pyle, A. M., and Fisher, P. B. (2002). mda-5: an interferon-inducible putative
RNA helicase with double-stranded RNA-dependent ATPase activity and melanoma growth-suppressive properties. Proc. Natl. Acad. Sci. U.S.A. 99, 637-642.

Karanja, R., Ingonga, J., Mwangi, M., Mwala, D., Lugalia, R., Magambo, J., and Tonui, W. (2011). Immunization with a combination of Leishmania major lipophosphoglycan (LPG) and Phlebotomus duboscqi salivary gland lysates (SGLs) abrogates protective effect of LPG against L. major in BALB/c mice. Afr. J. Health Sci. 18, 1-5.

Karplus, T. M., Jeronimo, S. M., Chang, H., Helms, B. K., Burns, T. L., Murray, J. C., Mitchell, A. A., Pugh, E. W., Braz, R. F., Bezerra, F. L., and Wilson, M. E. (2002). Association between the tumor necrosis factor locus and the clinical outcome of Leishmania chagasi infection. Infect. Immun. 70, 6919-6925.

Kaur, T., Sobti, R. C., and Kaur, S. (2011a). Cocktail of gp63 and Hsp70 induces protection against Leishmania donovani in BALB/c mice. Parasite Immunol. 33, 95-103.

Kaur, J., Kaur, T., and Kaur, S. (2011b). Studies on the protective efficacy and immunogenicity of Hsp70 and Hsp83 based vaccine formulations in Leishmania donovani infected BALB/c mice. Acta Trop. 119 50-56.

Kaye, P., and Scott, P. (2011). Leishmaniasis: complexity at the hostpathogen interface. Nat. Rev. Microbiol. 9, 604-615.

Kenney, R. T., Sacks, D. L., Gam, A. A., Murray, H. W., and Sundar, S. (1998). Splenic cytokine responses in Indian kala-azar before and after treatment. J. Infect. Dis. 177, 815-818.

Khalil, E. A., El Hassan, A. M., Zijlstra, E. E., Mukhtar, M. M., Ghalib, H. W., Musa, B., Ibrahim, M. E., Kamil, A. A., Elsheikh, M., Babiker, A., and Modabber, F. (2000). Autoclaved Leishmania major vaccine for prevention of visceral leishmaniasis: a randomised, double-blind, BCG-controlled trial in Sudan. Lancet 356, 1565-1569.

Khalil, E. A., Musa, A. M., Modabber, F., and El-Hassan, A. M. (2006). Safety and immunogenicity of a candidate vaccine for visceral leishmaniasis (Alum-precipitated autoclaved Leishmania major (BCG) in children: an extended phase II study. Ann. Trop. Paediatr. 26, 357-361.

Khamesipour, A., Dowlati, Y., Asilian, A., Hashemi - Fesharki, R., Javadi, A., Noazin, S., and Modabber, F. (2005). Leishmanization: use of an old method for evaluation of candidate vaccines against leishmaniasis. Vaccine 23, 3642-3648.

Kobayashi, M., Fitz, L., Ryan, M. Hewick, R. M., Clark, S. C., Chan, S., Loudon, R., Sherman, F., Perussia B., and Trinchieri, G. (1989). Identification and purification of natural killer cell stimulatory factor (NKSF), a cytokine with multiple biologic effects on human lymphocytes. J. Exp. Med.170, 827-845.

Kobukai, S., Kremers, G. J., Cobb, J. G., Baheza, R., Xie, J., Kuley, A. Zhu, M., and Pham, W. (2011). Induction of antitumor immunity by dendritic cells loaded with membrane-translocating mucin 1 Peptide antigen. Transl. Oncol. 4, 1-8.

Kubar, J., and Fragaki, K. (2005). Recombinant DNA-derived Leishmania proteins: from the laboratory to the field. Lancet. Infect. Dis. 5, 107-114.

Kumari, S., Samant, M., Misra, P., Khare, P., Sisodia, B., Shasany, A. K., and Dube, A. (2008a). Th1-stimulatory polyproteins of soluble Leishmania donovani promastigotes ranging from 89.9 to $97.1 \mathrm{kDa}$ offers longlasting protection against experimental visceral leishmaniasis. Vaccine 26, 5700-5711.

Kumari, S., Samant, M., Khare, P., Sundar, S., Sinha, S., and Dube, A. (2008b). Induction of Th1-type cellular responses in cured/exposed Leishmania-infected patients and hamsters against polyproteins of soluble Leishmania donovani promastigotes ranging from 89.9 to 97.1 kDa. Vaccine 26, 4813-4818.

Kushawaha, P. K., Gupta, R., Sundar, S., and Dube, A. (2011). Elongation factor-2, a Th1 stimulatory protein of Leishmania donovani, generates strong IFN- $\gamma$ and IL-12 response in cured Leishmania-infected patients/hamsters and protects hamsters against Leishmania challenge. J. Immunol. 187, 6417-6427.

Lamb, J. R., Zanders, E. D., Lake, P., Webster, R. G., Eckels, D. D., Woody, J. N., Green, N., Lerner, R. A., and Feldmann, M. (1984). Inhibition of T cell proliferation by antibodies to synthetic peptides. Eur. J. Immunol. 14, 153-157.

Lara, M. L., Layrisse, Z., Scorza, J. V., Garcia, E., Stoikow, Z., Granados, J., and Bias, W. Immunogenetics of human American cutaneous leishmaniasis. (1991). Study of HLA haplotypes in 24 families from Venezuela. Hum. Immunol. 30 129-135.
Larsen, M. H., Biermann, K., Chen, B., Hsu, T., Sambandamurthy, V. K. Lackner, A. A., Aye, P. P., Didier, P., Huang, D., Shao, L., Wei, H., Letvin, N. L., Frothingham, R., Haynes, B. F., Chen, Z. W., and Jacobs, W. R. Jr. (2009). Efficacy and safety of live attenuated persistent and rapidly cleared Mycobacterium tuberculosis vaccine candidates in non-human primates. Vaccine 27, 4709-4717.

Li, J., Hunter, C. A., and Farrell, J. P. (1999). Anti-TGF-beta treatment promotes rapid healing of Leishmania major infection in mice by enhancing in vivo nitric oxide production. J. Immunol. 162, 974-979.

Lima, K. M., Aparecida dos Santos, A., Rodrigues, J. M. Jr., and Silva, C. L. (2004). Vaccine adjuvant: it makes the difference. Vaccine 22, 2374-2379.

Lodge, R., Diallo, T. O., and Descoteaux, A. (2006). Leishmania donovani lipophosphoglycan blocks NADPH oxidase assembly at the phagosome membrane. Cell. Microbiol. 8, 1922-1931.

Macedo, A. B., Sánchez-Arcila, J. C., Schubach, A. O., Mendonça, S. C., Marins-Dos-Santos, A., de Fatima Madeira, M., Gagini, T., Pimentel, M. I., and De Luca, P. M. (2012). Multifunctional $\mathrm{CD}^{+}{ }^{+} \mathrm{T}$ cells in patients with American cutaneous leishmaniasis. Clin. Exp. Immunol. 167, 505-513.

Madagi, S., Patil, V. M., Sadegh, S., Singh, A. K., Garwal, B., Banerjee, A., Talambedu, U., and Bhattacharjee, B. (2011). Identification of membrane associated drug targets in Borrelia burgdorferi ZS7-subtractive genomics approach. Bioinformation 6, 356-359

Mandage, R. H., and Wadnerkar, A. S. (2010). Subtractive genomics approach to identify potential therapeutic targets in Leishmania donovani. Int. J. Pharm. Bio Sci. 1, 1-7.

Martinon, F., and Tschopp, J. (2005). NLRs join TLRs as innate sensors of pathogens. Trends Immunol. 26, 447-454.

Masih, S., Arora, S. K., and Vasishta, R. K. (2011). Efficacy of Leishma nia donovani ribosomal $\mathrm{P} 1$ gene as DNA vaccine in experimental visceral leishmaniasis. Exp. Parasitol. 129, 55-64.

Mazumder, T., Anam, K., and Ali, N. (2004). A mixed Th1/Th2 response elicited by a lip osomalformulation of Leishmania vaccine instructs Th1 responses and resistance to Leishmania donovani in susceptible BALB/c mice. Vaccine 22, 1162-1171. 
Mazumder, S., Maji, M., and Ali, N. (2011a). Potentiating effects of MPL on DSPC bearing cationic liposomes promote recombinant GP63 vaccine efficacy: high immunogenicity and protection. PLoS Negl. Trop. Dis. 5, e1429. doi:10.1371/journal.pntd.0001429

Mazumder, S., Maji, M., Das, A., and Ali, N. (2011b). Potency, efficacy and durability of DNA/DNA, DNA/protein and protein/protein based vaccination using gp63 against Leishmania donovani in BALB/c mice. PLoS ONE 6, e14644. doi:10.1371/journal.pone.0014644

Mazumder, S., Ravindran, R., Banerjee, A., and Ali, N. (2007). Non-coding pDNAbearingimmunostimulatory sequences co-entrapped with leishmanial antigens in cationic liposomes elicits almost complete protection against experimental visceral leishmaniasis in BALB/c mice. Vaccine 25, 8771-8781.

McConville, M. J., Bacic, A., Mitchell, G. F., and Handman, E. (1987). Lipophosphoglycan of Leishmania major that vaccinates against cutaneous leishmaniasis contains an alkylglycerophosphoinositol lipid anchor. Proc. Natl. Acad. Sci. U.S.A. 84, 8941-8945.

McShane, H., Behboudi, S., Goonetilleke, N., Brookes, R., and Hill, A. V. (2002). Protective immunity against Mycobacterium tuberculosis induced by dendritic cells pulsed with both CD8 (+)and $\mathrm{CD} 4(+)-\mathrm{T}$-cell epitopes from antigen 85A. Infect. Immun. 70, 1623-1626.

McSorley, S. J., Xu, D., and Liew, F. Y. (1997). Vaccine efficacy of Salmonella strains expressing glycoprotein 63 with different promoters. Infect. Immun. 65, 171-178.

Meddeb-Garnaoui, A., Toumi, A., Ghelis, H., Mahjoub, M., Louzir, H., and Chenik, M. (2010). Cellular and humoral responses induced by Leishmania histone $\mathrm{H} 2 \mathrm{~B}$ and its divergent and conserved parts in cutaneous and visceral leishmaniasis patients, respectively. Vaccine 28, 1881-1886.

Melby, P., Ogden, G. B., Flores, H. A., Zhao, W., Geldmacher, C., Biediger, N. M., Ahuja, S. K., Uranga, J., and Melendez, M. (2000). Identification of vaccine candidates for experimental visceral leishmaniasis by immunization with sequential fractions of a cDNA expression library. Infect. Immun. 68, 5595-5602.

Melby, P. C., Chandrasekar, B., Zhao, W., and Coe, J. E. (2001a). The hamster as a model of human visceral leishmaniasis: progressive disease and impaired generation of nitric oxide in the face of a prominent Th1-like cytokine response. J. Immunol. 166, 1912-1920.

Melby, P. C., Yang, J., Zhao, W., Perez, L. E., and Cheng, J. (2001b). Leishmania donovani $\mathrm{p} 36$ (LACK) DNA vaccine is highly immunogenic but not protective against experimental visceral leishmaniasis. Infect. Immun. 69, 4719-4725.

Mellman, I., and Steinman, R. M. (2001). Dendritic cells: specialized and regulated antigen processing machines. Cell 106, 255-258.

Mendez, S., Tabbara, K., Belkaid, Y., Bertholet, S., Verthelyi, D., Klinman, D., Seder, R. A., and Sacks, D. L. (2003). Coinjection with CpG-containing immunostimulatory oligodeoxynucleotides reduces the pathogenicity of a live vaccine against cutaneous leishmaniasis but maintains its potency and durability. Infect. Immun. 71, 5121-5129.

Milano, S., Di Bella, G., D’Agostino, P., Barbera, C., Caruso, R., La Rosa, M., Ferlazzo, V., Vitale, G., La Russa, C., Gambino, G., Chifari, N., Mansueto, S., and Cillari, E. (2002). IL-15 in human visceral leishmaniasis caused by Leishmania infantum. Clin. Exp. Immunol. 127, 360-365.

Misra, A., Dube, A., Shrivastava, B., Sharma, P., Shrivastava, J. K., and Katiyar, J. C. (2001). Successful vaccination against Leishmania donovani infection in Indian langur using alum-precipitated autoclaved Leishmania major with BCG. Vaccine 19 , 3485-3492.

Mizbani, A., Taheri, T., Zahedifard, F., Taslimi, Y., Azizi, H., Azadmanesh, K., Papadopoulou, B., and Rafati, S. (2009). Recombinant Leishmania tarentolae expressing the A2 virulence gene as a novel candidate vaccine against visceral leishmaniasis. Vaccine 28, 53-62.

Mizbani, A., Taslimi, Y., Zahedifard, F., Taheri, T., and Rafati, S. (2011). Effect of A2 gene on infectivity of the nonpathogenic parasite Leishmania tarentolae. Parasitol. Res. 109, 793-799.

Mohamed, H. S., Ibrahim, M. E., Miller, E. N., Peacock, C. S., Khalil, E. A., Cordell, H. J., Howson, J. M., El Hassan, A. M., Bereir, R. E., and Blackwell, J. M. (2003). Genetic susceptibility to visceral leishmaniasis in The Sudan: linkage and association with IL4 and IFNGR1. Genes Immun. 4, 351-355.

Mohamed, H. S., Ibrahim, M. E., Miller, E. N., White, J. K., Cordell, H. J., Howson, J. M., Peacock, C. S., Khalil,
E. A., El Hassan, A. M., and Blackwell, J. M. (2004). SLC11A1 (formerly NRAMP1) and susceptibility to visceral leishmaniasis in The Sudan. Eur. J. Hum. Genet. 12, 66-74.

Mohebali, M., Khamesipour, A. Mobedi, I., Zarei, Z., and HashemiFesharki, R. (2004). Double blind randomized efficacy field trial of alum precipitated autoclaved Leishmania major vaccine mixed with BCG against canine visceral leishmaniasis in Meshkin-Shahr district, I.R. Iran. Vaccine 22, 4097-4100.

Moll, H., and Berberich, C. (2001). Dendritic cell-based vaccination strategies: induction of protective immunity against leishmaniasis. Immunobiology 204, 659-666.

Momeni, A. Z., and Aminjavaheri, M. (1994). Clinical picture of cutaneous leishmaniasis in Isfahan, Iran. Int. J. Dermatol. 33, 260-265.

Momeni, A. Z., Jalayer, T., Emamjomeh, T., Khamesipour, A., Zicker, F., Ghassemi, R. L., Dowlati, Y., Sharifi, I., Aminjavaheri, M., Shafiei, I., Alimohammadian, M. H., HashemiFesharki, R., Nasseri, K., Godal, T., Smith, P. G., and Modabber F. (1999). A randomized double blind controlled trial of a killed L. major vaccine plus BCG against zoonotic cutaneous leishmaniasis in Iran. Vaccine 17, 466-472.

Morris, R. V., Shoemaker, C. B., David, J. R., Lanzaro, G. C., and Titus, R. G. (2001). Sandfly maxadilan exacerbates infection with Leishmania major and vaccinating against it protects against $L$. major infection. $J$. Immunol. 167, 5226-5230.

Moser, M., and Murphy, K. M. (2000). Dendritic cell regulation of $\mathrm{TH} 1-$ TH2 development. Nat. Immunol. 1, 199-205.

Mukherjee, M., Bhattacharyya, A., and Duttagupta, S. (2002). Serodiagnostic and immunoprophylactic potential of a $78 \mathrm{kDa}$ protein of Leishmania donovani of Indian origin. Med. Sci. Monit. 8, 117-122.

Müller, I., Fruth, U., and Louis, J. A. (1992). Immunobiology of experimental leishmaniasis. Med. Microbiol. Immunol. 181, 1-12.

Murray, H. W., and Cartelli, D. M. (1983). Killing of intracellular Leishmania donovani by human mononuclear phagocytes. Evidence for oxygen-dependent and independent leishmanicidal activity. J. Clin. Invest. 72, 32-44.

Murray, H. W., Rubin, B. Y., and Rothermel, C. D. (1983). Killing of intracellular Leishmania donovani by lymphokine-stimulated human mononuclear phagocytes. Evidence that interferon-gamma is the activating lymphokine. J. Clin. Invest. 72, 1506-1510.

Murray, H. W., Squires, K. E., Miralles, C. D., Stoeckle, M. Y., Granger, A. M., Granelli-Piperno, A., and Bogdan, C. (1992). Acquired resistance and granuloma formation in experimental visceral leishmaniasis. Differential $\mathrm{T}$ cell and lymphokine roles in initial versus established immunity. J. Immunol. 148, 1858-1863.

Murugaiyan, G., Mittal, A., LopezDiego, R., Maier, L. M., Anderson, D. E., and Weiner, H. L. (2009). IL-27 is a key regulator of IL-10 and IL-17 production by human $\mathrm{CD} 4+\mathrm{T}$ cells. J. Immunol. 183, 2435-2443.

Musa, A. M., Khalil, E. A., Mahgoub, F. A., Elgawi, S. H., Modabber, F., Elkadaru, A. E., Aboud, M. H., Noazin, S., Ghalib, H. W., and El-Hassan, A. M. (2008). Immunochemotherapy of persistent post-kala-azar dermal leishmaniasis: a novel approach to treatment. Trans. R. Soc. Trop. Med. Hyg. 102, 58-63.

Nadim, A., Javadian, E., TahvildarBidruni, G., and Ghorbani, M. (1983). Effectiveness of leishmanization in the control of cutaneous leishmaniasis. Bull. Soc. Pathol. Exot. Filiales 76, 377-383.

Nagill, R., and Kaur, S. (2010). Enhanced efficacy and immunogenicity of $78 \mathrm{kDa}$ antigen formulated in various adjuvants against murine visceral leishmaniasis. Vaccine $28,4002-4012$.

Nakhasi, H. L., Zheng, D., Callahan, L., Dave, J. R., and Liu, T. Y. (1989). Rubella virus: mechanism of attenuation in the vaccine strain (HPV77). Virus Res. 13, 231-243.

Napolitani, G., Rinaldi, A., Bertoni, F. Sallusto, F., and Lanzavecchia, A. (2005). Selected Toll like receptor agonist combinations synergistically trigger a $\mathrm{T}$ helper type 1-polarizing program in dendritic cells. Nat. Immunol. 6, 769-776.

Nateghi Rostami, M., Keshavarz Valian, H., Eskandari, S. E., Miramin Mohammadi, A., Shahrestani, S. T., Sarraf-Nejad, A., and Khamesipour, A. (2010). Differential in vitro $\mathrm{CD}^{+} / \mathrm{CD}^{+}{ }^{+} \mathrm{T}$-cell response to live vs. killed Leishmania major. Parasite Immunol. 32, 101-110.

Nicolas, L., Prina, E., Lang, T., and Milon, G. (2002). Real-time PCR for detection and quantitation of Leishmania in mouse tissues. J. Clin. Microbiol. 40, 1666-1669.

Nieto, A., Domínguez-Bernal, G., Orden, J. A., De La Fuente, R., Madrid-Elena, N., and Carrión, J. (2011). Mechanisms of resistance 
and susceptibility to experimental visceral leishmaniosis: BALB/c mouse versus syrian hamster model. Vet. Res. 42, 39.

Nogueira, F. S., Moreira, M. A., BorjaCabrera, G. P., Santos, F. N., Menz, I., Parra, L. E., Xu, Z., Chu, H. J., Palatnik-de-Sousa, C. B., and Luvizotto, M. C. (2005). Leishmune vaccine blocks the transmission of canine visceral leishmaniasis: absence of Leishmania parasites in blood, skin and lymph nodes of vaccinated exposed dogs. Vaccine 23, 4805-4810.

Nylén, S., and Akuffo, H. (2009). Tracing immunity to human leishmaniasis. Future Microbiol. 4, 241-254.

Nylén, S., Maasho, K., Söderstrom, K., Ilg, T., and Akuffo, H. (2003). Live Leishmania promastigotes can directly activate primary human natural killer cells to produce interferon-gamma. Clin. Exp. Immunol. 131, 457-467.

Nylén, S., Maurya, R., Eidsmo, L., Manandhar, K. D., Sundar, S., and Sacks, D. (2007). Splenic accumulation of IL-10 mRNA in T cells distinct from $\mathrm{CD} 4+\mathrm{CD} 25+($ Foxp3) regulatory $\mathrm{T}$ cells in human visceral leishmaniasis. J. Exp. Med. 204, 805-817.

Okwor, I., and Uzonna, J. (2008). Persistent parasites and immunologic memory in cutaneous leishmaniasis: implications for vaccine designs and vaccination strategies. Immunol. Res. 41, 123-136.

Olivier, M., Gregory, D. J., and Forget, G. (2005). Subversion mechanisms by which Leishmania parasites can escape the host immune response: a signaling point of view Clin. Microbiol. Rev. 18, 293-305.

Ozbilge, H., Aksoy, N., Gurel, M. S., and Yazar, S. (2006). IgG and IgG subclass antibodies in patients with active cutaneous leishmaniasis. J. Med. Microbiol. 55, 1329-1331.

Palatnik de Sousa, C. B., Moreno, M. B., Paraguai de Souza, E., and Borojevic, R. (1994a). The FML-vaccine (Fucose-Mannose Ligand) protects hamsters from experimental KalaAzar. J. Braz. Assoc. Adv. Sci. 46, 290-296.

Palatnik de Sousa, C. B., Paraguai de Souza, E., Gomes, E. M., and Borojevic, R. (1994b). Experimental murine Leishmania donovani infection: immunoprotection by the fucose-mannose ligand (FML). Braz. J. Med. Biol. Res. 27, 547-555.

Palatnik de Sousa, C. B., Gomes, E. M., de Souza, E. P., dos Santos, W. R., de Macedo, S. R., de Medeiros, L. V., and Luz, K. (1996). The FML (fucose mannose ligand) of Leishmania donovani: a new tool in diagnosis, prognosis, transfusional control and vaccination against human kala-azar. Rev. Soc. Bras. Med. Trop. 29, 153-163.

Palatnik de Sousa, C. B., Santos, W. R., Casas, C. P., Paraguai de Souza, E., Tinoco, L. W., da Silva, B. P., Palatnik, M., and Parente, J. P. (2004). Protective vaccination against murine visceral leishmaniasis using aldehyde-containing Quillaja saponaria sapogenins. Vaccine 22, 2470-2479.

Papadopoulou, B., Roy, G., Breton, M., Kündig, C., Dumas, C., Fillion, I. Singh, A. K., Olivier, M., and Ouellette, M. (2002). Reduced infectivity of a Leishmania donovani biopterin transporter genetic mutant and its use as an attenuated strain for vaccination. Infect. Immun. 70, 62-68.

Paraguai-de-Souza, E., Bernardo, R. R., Palatnik, M., and Palatnik-deSousa, C. B. (2001). Vaccination of Balb/c mice against experimental visceral leishmaniasis with the GP36 glycoprotein antigen of Leishmania donovani. Vaccine 19, 3104-3115.

Parra, L. E., Borja-Cabrera, G. P., Santos, F. N., Souza, L. O., Palatnikde-Sousa, C. B., and Menz, I. (2007). Safety trial using the Leishmune vaccine against canine visceral leishmaniasis in Brazil. Vaccine 25, 2180-2186.

Pearson, R. D., and Sousa, A. Q. (1996). Clinical spectrum of leishmaniasis. Clin. Infect. Dis. 22, 1-13.

Perumal, D., Lim, C. S., Sakharkar, K. R. and Sakharkar, M. K. (2007). Differential genome analyses of metabolic enzymes in Pseudomonas aeruginosa for drug target identification. In Silico Biol. 7, 453-465.

Peters, N., and Sacks, D. (2006). Immune privilege in sites of chronic infection: Leishmania and regulatory $\mathrm{T}$ cells. Immunol. Rev. 213, 159-179.

Petzl-Erler, M. L., Belich, M. P., and Queiroz-Telles, F. (1991). Association of mucosal leishmaniasis with HLA. Hum. Immunol. 32, 254-260.

Piccioli, D., Sbrana, S., Melandri, E., and Valiante, N. M. (2002). Contactdependent stimulation and inhibition of dendritic cells by natural killer cells. J. Exp. Med. 195, 335-341. Pitta, M. G., Romano, A., Cabantous, S., Henri, S., Hammad, A., Kouriba, B., Argiro, L., el Kheir, M., Bucheton, B., Mary, C., El-Safi, S. H., and Dessein, A. (2009). IL-17 and IL-22 are associated with protection against human kala azar caused by Leishmania donovani. J. Clin. Invest. 119, 2379-2387.

Praveena, A., Sindhuja, R., Anuradha, V., and Habeeb, S. K. M. (2011). Putative drug target identification for chlamydia trachomatis: an in silico proteome analysis. Int. J. Biomed. Res. 2, 151-160.

Prina, E., Abdi, S. Z., Lebastard, M., Perret, E, Winter, N., and Antoine, J. C. (2004). Dendritic cells as host cells for the promastigote and amastigote stages of Leishmania amazonensis: the role of opsonins in parasite uptake and dendritic cell maturation. J. Cell. Sci. 117, 315-325.

Rachamim, N., and Jaffe, C. L. (1993). Pure protein from Leishmania donovani protects mice against both cutaneous and visceral leishmaniasis. $J$. Immunol. 150, 2322-2331.

Rafati, S., Zahedifard, F., and Nazgouee, F. (2006). Prime-boost vaccination using cysteine proteinases type I and II of Leishmania infantum confers protective immunity in murine visceral leishmaniasis. Vaccine 24 2169-2175.

Raman, V. S., Bhatia, A., Picone, A., Whittle, J., Bailor, H. R., O’Donnell, J., Pattabhi, S., Guderian, J. A., Mohamath, R., Duthie, M. S., and Reed, S. G. (2010). Applying TLR synergy in immunotherapy: implications in cutaneous leishmaniasis. J. Immunol. 185, 1701-1710.

Ravindran, R., Anam, K., Bairagi, B. C., Saha, B., Pramanik, N., Guha, S. K., Goswami, R. P., Banerjee, D., and Ali, N. (2004). Characterization of immunoglobulin $\mathrm{G}$ and its subclass response to Indian kala-azar infection before and after chemotherapy. Infect. Immun. 72, 863-870.

Ravindran, R., Bhowmick, S., Das, A. and Ali, N. (2010). Comparison of BCG, MPL and cationic liposome adjuvant systems in leishmanial antigen vaccine formulations against murine visceral leishmaniasis. BMC Microbiol. 10, 181 doi:10.1186/1471-2180-10-181

Ravindran, R., Maji, M., and Ali, N. (2012). Vaccination with liposomal leishmanial antigens adjuvanted with MPL-TDM confers long-term protection against visceral leishmaniasis through human adminstrable route. Mol. Pharm. 9, 59-70.

Reed, S. G., Coler, R. N., and CamposNeto, A. (2003). Development of a leishmaniasis vaccine: the importance of MPL. Expert Rev. Vaccines 2, 239-252.

Remer, K. A., Apetrei, C., Schwarz, T., Linden, C., and Moll, $\mathrm{H}$.
(2007). Vaccination with plasmacytoid dendritic cells induces protection against infection with Leishmania major in mice. Eur. J. Immunol. 37, 2463-2473.

Resende, D. M., Caetano, B. C., Dutra, M. S., Penido, M. L., Abrantes, C. F., Verly, R. M., Resende, J. M., Piló-Veloso, D., Rezende, S. A., Bruna-Romero, O., Fernandes, A. P., and Gazzinelli, R. T. (2008). Epitope mapping and protective immunity elicited by adenovirus expressing the Leishmania amastigote specific A2 antigen: correlation with IFN-gamma and cytolytic activity by CD8+ $\mathrm{T}$ cells. Vaccine 26 , 4585-4593.

Rohtagi, A., Agarwal, S. K., Bose, M., Chattopadhya, D., and Saha, K. (1996). Blood, bone marrow and splenic lymphocyte subset profiles in Indian visceral leishmaniasis. Trans. R. Soc. Trop. Med. Hyg. 90, 431-434. Russo, D. M., Jardim, A, Carvalho, E. M., Sleath, P. R., Armitage, R. J., Olafson, R. W., and Reed, S. G. (1993). Mapping human T cell epitopes in Leishmania gp63. Identification of cross-reactive and speciesspecific epitopes. J. Immunol. 150, 932-939.

Ryan, J. R., Smithyman, A. M., Rajasekariah, G. H., Hochberg, L., Stiteler, J. M., and Martin, S. K. (2002). Enzyme-linked immunosorbent assay based on soluble promastigote antigen detects immunoglobulin M (IgM) and IgG antibodies in sera from cases of visceral and cutaneous leishmaniasis. $J$. Clin. Microbiol. 40, 1037-1043.

Sachdeva, R., Banerjea, A. C., Malla, N., and Dubey, M. L. (2009). Immunogenicity and efficacy of single antigen Gp63, polytope and polytope HSP70 DNA vaccines against visceral Leishmaniasis in experimental mouse model. PLoS One 4, e7880.

Sacks, D. L. (2001). Leishmania-sand fly interactions controlling speciesspecific vector competence. Cell. Microbiol. 3, 189-196.

Sacks, D. L., Lal, S. L., Shrivastava, S. N., Blackwell, J., and Neva, F. A. (1987). An analysis of $\mathrm{T}$ cell responsiveness in Indian kala-azar. J. Immunol. 138, 908-913.

Saha, S., Mondal, S., Banerjee, A., Ghose, J, Bhowmick, S., and Ali, N. (2006). Immune responses in kala-azar. Indian J. Med. Res. 123, 245-266.

Saha, S., Mondal, S., Ravindran, R., Bhowmick, S., Modak, D., Mallick, S., Rahman, M., Kar, S., Goswami, R., Guha, S. K., Pramanik, N., Saha, B., and Ali, N. (2007). IL-10- and 
TGF-beta-mediated susceptibility in kala-azar and post-kala-azar dermal leishmaniasis: the significance of amphotericin B in the control of Leishmania donovani infection in India. J. Immunol. 179, 5592-5603.

Sakharkar, K. R., Sakharkar, M. K., and Chow, V. T. K. (2004). A novel genomics approach for the identification of drug targets in pathogens, with special reference to Pseudomonas aeruginosa. In silico Biol. (Gedrukt) 4, 0028.

Saldarriaga, O. A., Travi, B. L., Park, W., Perez, L. E., and Melby, P. C. (2006). Immunogenicity of a multicomponent DNA vaccine against visceral leishmaniasis in dogs. Vaccine 24, 1928-1940.

Samant, M., Gupta, R., Kumari, S., Misra, P., Khare, P., Kushawaha, P. K., Sahasrabuddhe, A. A., and Dube, A. (2009). Immunization with the DNA-encoding N-terminal domain of proteophosphoglycan of Leishmania donovani generates Thl-type immunoprotective response against experimental visceral leishmaniasis. J. Immunol. 183, 470-479.

Sanabria, M. X., Vargas-Inchaustegui, D. A., Xin, L., and Soong, L. (2008). Role of natural killer cells in modulating dendritic cell responses to Leishmania amazonensis infection. Infect. Immun. 76, 5100-5109.

Santos, W. R., de Lima, V. M., de Souza, E. P., Bernardo, R. R., Palatnik, M., and Palatnik de Sousa, C. B. (2002). Saponins, IL12 and BCG adjuvant in the FML-vaccine formulation against murine visceral leishmaniasis. Vaccine 21, 30-43.

Santos, W. R., Paraguai de Souza, E., Palatnik, M., and Palatnik de Sousa, C. B. (1999). Vaccination of Swiss albino mice against experimental visceral leishmaniasis with the FML antigen of Leishmania donovani. Vaccine 17, 2554-2561.

Saraiva, E. M., de Figueiredo Barbosa, A., Santos, F. N., BorjaCabrera, G. P., Nico, D., Souza, L. O., de Oliveira Mendes-Aguiar, C., de Souza, E. P., Fampa, P., Parra, L. E., Menz, I., Dias, J. G. Jr., de Oliveira, S. M., and Palatnikde-Sousa, C. B. (2006). The FMLvaccine (Leishmune) against canine visceral leishmaniasis: a transmission blocking vaccine. Vaccine 24, 2423-2431.

Scharton, T. M., and Scott, P. (1993). Natural killer cells are a source of interferon gamma that drives differentiation of CD4+ T cell subsets and induces early resistance to Leishmania major in mice. J. Exp. Med. 178, 567-577.
Scott, P. (2003). Development and regulation of cell mediated immunity in experimental leishmaniasis. Immunol. Res. 27, 489-498.

Selvapandiyan, A., Dey, R., Nylen, S., Duncan, R., Sacks, D., and Nakhasi, H. L. (2009). Intracellular replication-deficient Leishmania donovani induces long lasting protective immunity against visceral leishmaniasis. J. Immunol. 183, 1813-1820.

Shadab, M., and Ali, N. (2011). Evasion of host defence by Leishmania donovani: subversion of signaling pathways. Mol. Biol. Int. 2011, 343961.

Sharifi, I., Fekri, A. R., Aflatonian, M. R., Khamesipour, A., Nadim, A., Mousavi, M. R., Momeni, A. Z., Dowlati, Y., Godal, T., Zicker, F., Smith, P. G., and Modabber, F. (1998). Randomised vaccine trial of single dose of killed L. major plus BCG against anthroponotic cutaneous leishmanisis in Bam, Iran. Lancet 351, 1540-1543.

Sharma, A., and Madhubala, R. (2009). Ubiquitin conjugation of open reading frame F DNA vaccine leads to enhanced cell-mediated immune response and induces protection against both antimony-susceptible and -resistant strains of Leishmania donovani. J. Immunol. 183, 7719-7731.

Sharma, M. C., Gupta, A. K., Das, V. N., Verma, N., Kumar, N., Saran, R., and Kar, S. K. (2000). Leishmania donovani in blood smears of asymptomatic persons. Acta Trop. 76, 195-196.

Silvestre, R., Cordeiro-Da-Silva, A., Santarém, N., Vergnes, B., Sereno, D., and Ouaissi, A. (2007). SIR2deficient Leishmania infantum induces a defined IFN-gamma/IL10 pattern that correlates with protection. J. Immunol. 179, 3161-3170.

Sinha, S., Sundaram, S., Singh, A. P., and Tripathi, A. (2011). A gp63 based vaccine candidate against visceral leishmaniasis. Bioinformation 5, 320-325.

Skeiky, Y. A., Coler, R. N., Brannon, M., Stromberg, E., Greeson, K., Crane, R. T., Webb, J. R., Campos-Neto, A., and Reed, S. G. (2002). Protective efficacy of a tandemly linked, multi-subunit recombinant leishmanial vaccine (Leish-111f) formulated in MPL adjuvant. Vaccine 20, 3292-3303.

Soto, M., Requena, J. M., Quijada, L., Perez, M. J., Nieto, C. G., Guzman, F., Patarroyo, M. E., and Alonso, C.
(1999). Antigenicity of the Leishmania infantum histones $\mathrm{H} 2 \mathrm{~B}$ and $\mathrm{H} 4$ during canine viscerocutaneous leishmaniasis. Clin. Exp. Immunol. 115, 342-349.

Späth, G. F., Epstein, L., Leader, B., Singer, S. M., Avila, H. A., Turco, S. J., and Beverley, S. M. (2000) Lipophosphoglycan is a virulence factor distinct from related glycoconjugates in the protozoan parasite Leishmania major. Proc. Natl. Acad. Sci. U.S.A. 97, 9258-9263.

Spitzer, N., Jardim, A., Lippert, D., and Olafson, R. W. (1999). Long-term protection of mice against Leishmania major with a synthetic peptide vaccine. Vaccine 17, 1298-1300.

Squires, K. E., Rosenkaimer, F., Sherwood, J. A., Forni, A. L., Were, J. B., and Murray, H. W. (1993). Immunochemotherapy for visceral leishmaniasis: a controlled pilot trial of antimony versus antimony plus interferon-gamma. Am. J. Trop. Med. Hyg. 48, 666-669.

Stäger, S., Alexander, J., Kirby, A. C., Botto, M., Rooijen, N. V., Smith, D. F., Brombacher, F., and Kaye, P. M. (2003). Natural antibodies and complement are endogenous adjuvants for vaccine-induced CD8+ T-cell responses. Nat. Med. 9, 1287-1292.

Stager, S., Smith, D. F., and Kaye, P. M. (2000). Immunization with a recombinant stage-regulated surface protein from Leishmania donovani induces protection against visceral leishmaniasis. J. Immunol. 165 7064-7071.

Stern, A. S., Podlaski, F. J., Hulmes, J. D., Pan, Y. C., Quinn, P. M., Wolitzky, A. G., Familletti, P. C., Stremlo, D. L., Truitt, T., Chizzonite, R., and Gately, M. K. (1990). Purification to homogeneity and partial characterization of cytotoxic lymphocyte maturation factor from human B-lymphoblastoid cells. Proc. Natl. Acad. Sci. U.S.A. 87, 6808-6812.

Stobie, L., Gurunathan, S., Prussin, C., Sacks, D. L., Glaichenhaus, N., Wu, C.-Y., and Seder, R. A. (2000). The role of antigen and IL-12 in sustaining Thl memory cells in vivo: $\mathrm{IL}-12$ is required to maintain memory/effector Th1 cells sufficient to mediate protection to an infectious parasite challenge. Proc. Natl. Acad. Sci. U.S.A. 97 8427-8432.

Sukumaran, B., Tewary, P., Saxena, S. and Madhubala, R. (2003). Vaccination with DNA encoding ORFF antigen confers protective immunity in mice infected with Leishmania donovani. Vaccine 21, 1292-1299.
Sundar, S., and Murray, H. W. (1995). Effect of treatment with interferongamma alone in visceral leishmaniasis. J. Infect. Dis. 172, 1627-1629.

Sundar, S., Reed, S. G., Sharma, S., Mehrotra, A., and Murray, H. W. (1997a). Circulating $\mathrm{T}$ helper 1 (Th1) cell- and Th2 cell-associated cytokines in Indian patients with visceral leishmaniasis. Am. J. Trop. Med. Hyg. 56, 522-525.

Sundar, S., Singh, V. P., Sharma, S., Makharia, M. K., and Murray, H. W. (1997b). Response to interferongamma plus pentavalent antimony in Indian visceral leishmaniasis. $J$. Infect. Dis. 176, 1117-1119.

Sundar, S., Rosenkaimer, F., Lesser, M. L., and Murray, H. W. (1995). Immunochemotherapy for a systemic intracellular infection: accelerated response using interferongamma in visceral leishmaniasis. $J$. Infect. Dis. 171, 992-996.

Sundar, S., Rosenkaimer, F., and Murray, H. W. (1994). Successful treatment of refractory visceral leishmaniasis in India using antimony plus interferon-gamma. J. Infect. Dis. 170, 659-662.

Tejle, K., Lindroth, M., Magnusson, K. E., and Rasmusson, B. (2008). Wild-type Leishmania donovani promastigotes block maturation, increase integrin expression and inhibit detachment of human monocyte-derived dendritic cells - the influence of phosphoglycans. FEMS Microbiol. Lett. 279, 92-102.

Tewary, P., Jain, M., Sahani, M. H., Saxena, S., and Madhubala, R. (2005). A heterologous primeboost vaccination regimen using ORFF DNA and recombinant ORFF protein confers protective immunity against experimental visceral leishmaniasis. J. Infect. Dis. 191, 2130-2137.

Tewary, P., Pandya, J., Mehta, J., Sukumaran, B., and Madhubala, R. (2004a). Vaccination with Leishmania soluble antigen and immunostimulatory oligodeoxynucleotides induces specific immunity and protection against Leishmania donovani infection. FEMS Immunol. Med. Microbiol. 4, 241-248.

Tewary, P., Sukumaran, B., Saxena, S., and Madhubala, R. (2004b). Immunostimulatory oligodeoxynucleotides are potent enhancers of protective immunity in mice immunized with recombinant ORFF leishmanial antigen. Vaccine 22, 3053-3060.

Titus, R. G., and Ribeiro, J. M. (1988). Salivary gland lysates from the sand 
fly Lutzomyia longipalpis enhance Leishmania infectivity. Science 239, 1306.

Tonui, W. K., Mbati, P. A., Anjili, J. O., Orago, A. S., Turco, S. J., Githure, J. I., and Koech, D. K. (2001). Transmission blocking vaccine studies in lelishmaniasis: I. Lipophosphoglycan is a promising transmission blocking vaccine molecule against cutaneous leishmaniasis. East Afr. Med. J. 78, 84-89.

Tracey, K. J., Wei, H., Manogue, K. R., Fong, Y., Hesse, D. G., Nguyen, H. T., Kuo, G. C., Beutler, B., Cotran, R. S., Cerami, A., and Lowry, S. F. (1988). Cachectin/tumor necrosis factor induces cachexia, anemia, and inflammation. J. Exp. Med. 167, 1211-1227.

Trinchieri, G. (1993). Interleukin-12 and its role in the generation of $\mathrm{TH} 1$ cells. Immunol. Today 14, 335-338.

Tsagozis, P., Karagouni, E., and Dotsika, E. (2004). Dendritic cells pulsed with peptides of gp63 induce differential protection against experimental cutaneous leishmaniasis. Int. J. Immunopathol. Pharmacol. 17, 343-352.

Valenzuela, J. G., Garfield, M., Rowton, E. D., and Pham, V. M. (2004). Identification of the most abundant secreted proteins from the salivary glands of the sand fly Lutzomyia longipalpis, vector of Leishmania chagasi. J. Exp. Biol. 7, 3717-3729.

Vélez, I. D., Gilchrist, K., Arbelaez, M. P., Rojas, C. A., Puerta, J. A., Antunes, C. M., Zicker, F., and Modabber, F. (2005). Failure of a killed Leishmania amazonensis vaccine against American cutaneous leishmaniasis in Colombia. Trans. R. Soc. Trop. Med. Hyg. 99, 593-598.

Vélez, I. D., Gilchrist, K., Martínez, S., Ramírez-Pineda, J. R., Ashman, J. A., Alves, F. P., Coler, R. N., Bogatzki, L. Y., Kahn, S. J., Beckmann, A. M.,
Cowgill, K. D., Reed, S. G., and Piazza, F. M. (2009). Safety and immunogenicity of a defined vaccine for the prevention of cutaneous leishmaniasis. Vaccine 28, 329-337.

Vinet, A. F., Fukuda, M., Turco, S. J., and Descoteaux, A. (2009). The Leishmania donovani lipophosphoglycan excludes the vesicular proton-ATPase from phagosomes by impairing the recruitment of synaptotagmin V. PLoS Pathog. 5, e1000628. doi:10.1371/journal.ppat. 1000628

Vouldoukis, I., Bécherel, P. A., RiverosMoreno, V., Arock, M., da Silva, O., Debré, P., Mazier, D., and Mossalayi, M. D. (1997). Interleukin-10 and interleukin-4 inhibit intracellular killing of Leishmania infantum and Leishmania major by human macrophages by decreasing nitric oxide generation. Eur. J. Immunol. 4, 860-865.

Walker, P. S., Scharton-Kersten, T., Krieg, A. M., Love-Homan, L., Rowton, E. D., Udey, M. C., and Vogel, J. C. (1999). Immunostimulatory oligodeoxynucleotides promote protective immunity and provide systemic therapy for leishmaniasis via IL-12- and IFN- $\gamma$-dependent mechanisms. Proc. Natl. Acad. Sci. U.S.A. 96, 6970-6975.

Walton, B. C., and Valverde, L. (1979). Racial difference in espundia. Ann. Trop. Med. Parasitol. 73, 23-29.

Wang, Y., Chen, Y., Xin, L., Beverley, S. M., Carlsen, E. D., Popov, V., Chang, K. P., Wang, M., and Soong, L. (2011). Differential microbicidal effects of human histone proteins $\mathrm{H} 2 \mathrm{~A}$ and $\mathrm{H} 2 \mathrm{~B}$ on Leishmania promastigotes and amastigotes. Infect. Immun. 79, 1124-1133.

Weigle, K., and Saravia, N. G. (1996). Natural history, clinical evolution, and the host-parasite interaction in
New World cutaneous leishmaniasis. Clin. Dermatol. 14, 433-450.

Wilson, M. E., Jeronimo, S. M. and Pearson, R. D. (2005). Immunopathogenesis of infection with the visceralizing Leishmania species. Microb. Pathog. 38, 147-160.

Woelbing, F., Kostka, S. L., Moelle, K. Belkaid, Y., Sunderkoetter, C., Verbeek, S., Waisman, A., Nigg, A. P., Knop, J., Udey, M. C., and von Stebut, E. (2006). Uptake of Leishmania major by dendritic cells is mediated by Fcgamma receptors and facilitates acquisition of protective immunity. J. Exp. Med. 203, 177-188.

Wu, W., Huang, L., and Mendez, S. (2010). A live Leishmania major vaccine containing $\mathrm{CpG}$ motifs induces the de novo generation of Th17 cells in C57BL/6 mice. Eur. J. Immunol. 40, 2517-2527.

Yam, K. K., Hugentobler, F., Pouliot, P., Stern, A. M., Lalande, J. D. Matlashewski, G., Olivier, M., and Cousineau, B. (2011). Generation and evaluation of A2-expressing Lactococcus lactis live vaccines against Leishmania donovani in BALB/c mice. J. Med. Microbiol. 60, 1248-1260.

Zadeh-Vakili, A., Taheri, T., Taslimi, Y., Doustdari, F., Salmanian, A. H. and Rafati, S. (2004). Immunization with the hybrid protein vaccine, consisting of Leishmania major cysteine proteinases Type I (CPB) and Type II (CPA), partially protects against leishmaniasis. Vaccine 22, 1930-1940.

Zambrano-Villa, S., Borjas, D., Carrero, J., and Ortiz-Ortiz, L. (2002). How protozoan parasites evade the immune response. Trends Parasitol. 18, 272-278.

Zhu, Q., Egelston, C., Vivekanandhan, A., Uematsu, S., Akira, S., Klinman, D. M., Belyakov, I. M., and Berzofsky,
J. A. (2008). Toll-like receptor ligands synergize through distinct dendritic cell pathways to induce $\mathrm{T}$ cell responses: implications for vaccines. Proc. Natl. Acad. Sci. U.S.A. 105, 16260-16265.

Zijlstra, E. E., el-Hassan, A. M., Ismael, A., and Ghalib, H. W. (1994). Endemic kala-azar in eastern Sudan: a longitudinal study on the incidence of clinical and subclinical infection and post-kala-azar dermal leishmaniasis. Am. J. Trop. Med. Hyg. 51, 826-836.

Zwingenberger, K., Harms, G., Pedrosa, C., Omena, S., Sandkamp, B., and Neifer, S. (1990). Determinants of the immune response in visceral leishmaniasis: evidence for predominance of endogenous interleukin 4 over interferongamma production. Clin. Immunol. Immunopathol. 57, 242-249.

Conflict of Interest Statement: The authors declare that the research was conducted in the absence of any commercial or financial relationships that could be construed as a potential conflict of interest.

Received: 05 January 2012; accepted: 14 April 2012; published online: 15 May 2012.

Citation: Das A and Ali N (2012) Vaccine development against Leishmania donovani. Front. Immun. 3:99. doi: 10.3389/fimmu.2012.00099

This article was submitted to Frontiers in Microbial Immunology, a specialty of Frontiers in Immunology.

Copyright (C) 2012 Das and Ali. This is an open-access article distributed under the terms of the Creative Commons Attribution Non Commercial License, which permits non-commercial use, distribution, and reproduction in other forums, provided the original authors and source are credited. 